\title{
ГЕНЕЗИС И ИЗОТОПНЫЙ СОСТАВ Nd ЖЕЛЕЗОМАРГАНЦЕВЫХ ОБРАЗОВАНИЙ ОХОТСКОГО МОРЯ И КУРИЛЬСКОЙ ОСТРОВНОЙ ДУГИ
}

Михайлик П. Е., Вишневская И. А., Михайлик Е. В., Блохин М. Г., Червяковская М. В., Рашидов В. A., Ren X. .

\begin{abstract}
Аннотация
Проведены исследования изотопного состава неодима железомарганцевых образований (ЖМО) центральной части Охотского моря и Курильской островной дуги. Результаты показали неоднородность изотопного состава Nd образцов диагенетических ЖМО в котловине Дерюгина. Положительные значения $\varepsilon N d$ здесь могут являться, как результатом привноса терригенной примеси, так и быть следствием диффузной эндогенной подпитки. Образцы, отобранные с подводного хребта Зонне, отражают величину $\varepsilon \mathrm{Nd}$ морской воды (-3.2). Значение $\varepsilon \mathrm{Nd}$ гидрогенной корки Вулкана 7.14 составляет -3.4, что соответствует величине этого показателя для тихоокеанских вод. В ЖМО Вулкана $5.5 \varepsilon \mathrm{Nd}=-2.0$. Такое повышение изотопного состава неодима может быть следствием умеренного разбавления морской водой гидротермального флюида, а также свидетельствовать о наличии в пробе обломков вулканитов. Наибольшее значение $\varepsilon \mathrm{Nd}(+4.4)$ установлено для вулканокластического песчаника пропитанного гидрооксидами Fe и $\mathrm{Mn}$, такая величина $\varepsilon \mathrm{Nd}$ отражает смешение вулканомиктового материала с гидротермальным.
\end{abstract}

\section{Ключевые слова:}

Железомарганцевые образования, Охотское море, Курильская островная дуга, генезис, изотопный состав неодима 


\title{
ГЕНЕЗИС И ИЗОТОПНЫЙ СОСТАВ Nd ЖЕЛЕЗОМАРГАНЦЕВЫХ ОБРАЗОВАНИЙ ОХОТСКОГО МОРЯ И КУРИЛЬСКОЙ ОСТРОВНОЙ ДУГИ
}

\author{
П.Е. Михайлик ${ }^{1}$, И.А. Вишневская ${ }^{2,3,4}$, Е.В. Михайлик ${ }^{1}$, М.Г. Блохин ${ }^{1}$, М.В. \\ Червяковская ${ }^{4}$, В.А. Рашидов ${ }^{5}$, Кс. Рен $^{6}$ \\ ${ }^{1}$ Дальневосточный геологический институт ДВО РАН, 690022, Владивосток, просп. 100- \\ летия Владивостока, 159, Россия \\ ${ }^{2}$ Институт геохимии и аналитической химии им. В.И. Вернадского РАН, 119991, 2. \\ Москва, ул. Косыгина, д.19, Россия \\ ${ }^{3}$ Новосибирский государственный университет, 630090, г. Новосибирск, ул. Пирогова, 1, \\ Россия \\ ${ }^{4}$ Институт геологии и геохимии им. А.Н. Заварицкого УО РАН, 620016 Екатеринбург, ул. \\ Академика Вонсовского, 15, Россия \\ ${ }^{5}$ Институт вулканологии и сейсмологии ДВО РАН, 683006, Петропавловск-Камчатский, \\ бульвар Пийпа, 9, Россия \\ ${ }^{6}$ Первый океанографический институт МПР КНР, 266061 Циндао, Китай
}

\section{АННОТАЦИЯ}

Проведены исследования изотопного состава неодима железомарганцевых образований (ЖМО) центральной части Охотского моря и Курильской островной дуги. Результаты показали неоднородность изотопного состава $\mathrm{Nd}$ образцов диагенетических ЖМО в котловине Дерюгина. Положительные значения $\varepsilon_{\mathrm{Nd}}$ здесь могут являться, как результатом привноса терригенной примеси, так и быть следствием диффузной эндогенной подпитки. Образцы, отобранные с подводного хребта Зонне, отражают величину $\varepsilon_{\mathrm{Nd}}$ морской воды (-3.2). Значение $\varepsilon_{\mathrm{Nd}}$ гидрогенной корки Вулкана 7.14 составляет -3.4, что соответствует величине этого показателя для тихоокеанских вод. В ЖМО Вулкана $5.5 \varepsilon_{\mathrm{Nd}}=-2.0$. Такое повышение изотопного состава неодима может быть следствием умеренного разбавления морской водой гидротермального флюида, а также свидетельствовать о наличии в пробе обломков вулканитов. Наибольшее значение $\varepsilon_{\mathrm{Nd}}$ $(+4.4)$ установлено для вулканокластического песчаника пропитанного гидрооксидами Fe и $\mathrm{Mn}$, такая величина $\varepsilon_{\mathrm{Nd}}$ отражает смешение вулканомиктового материала с гидротермальным.

Железомарганцевые образования, изотопный состав неодима, генезис, Курильская островная дуга, Охотское море

\section{ВВЕДЕНИЕ}

Железомарганцевые образования (ЖМО) привлекают к себе внимание не только как перспективное сырье на $\mathrm{Mn}$, Со и другие стратегические металлы, но и как «архив», фиксирующий кайнозойскую историю развития Земли [Hein et al., 1993; Koschinsky et al., 1996; Frank et al., 1999; van de Flierdt et al., 2003; Claude et al., 2005; Ito, Komuro, 2006; Usui et al., 2007; Nielsen et al., 2009; Horner et al., 2010]. Предыдущими исследованиями было показано, что ЖМО отражают эволюцию водных масс Мирового океана [Jones et al., 2008; Siddall et al., 2008], маркируют ледниковые/межледниковые периоды [Burton, Vance, 2000; Piotrowski et al., 2005; Roberts et al., 2010], «записывают» вариацию интенсивности поставки вулканогенного, эолового и космогенного вещества в океаны [Frank, 2002; Jeandel et al., 2007]. Все эти результаты были получены благодаря изучению изотопного состава ЖМО, в частности неодима [van de Flierdt et al., 2006; Gutjahr et al., 2007]. 
Радиогенный ${ }^{143} \mathrm{Nd}$ образуется при распаде радиоактивного ${ }^{147} \mathrm{Sm}$, что приводит к изменениям изотопного отношения ${ }^{143} \mathrm{Nd} /{ }^{144} \mathrm{Nd}$ в горных породах разного генезиса. Однако, в связи с большим периодом полураспада ${ }^{147} \mathrm{Sm}$, разница в изотопном составе $\mathrm{Nd}$ разных горных пород и вод довольно невелика, поэтому используется показатель $\varepsilon_{\mathrm{Nd}}$. Его величина вычисляется относительно «однородного хондритового резервуара (CHUR)», для достаточно молодых пород используют следующее уравнение:

$$
\left.\left.\varepsilon_{N d}(0)=\mid \frac{\left(\begin{array}{c}
\frac{143}{\square d 4} \\
{ }_{\square} N d
\end{array}\right)}{\left(\frac{{ }_{\square}^{143} N d}{144}{ }_{\square} N d\right.}\right)_{C H U R}\right) \cdot 10000
$$

где $\left({ }^{143} \mathrm{Nd} /{ }^{144} \mathrm{Nd}\right)$ изотопный состав $\mathrm{Nd}$ в природном образце, $\left({ }^{143} \mathrm{Nd} /{ }^{144} \mathrm{Nd}\right)_{\text {CHUR }}$ - в «однородном хондритовом резервуаре» в настоящий момент, которое равно 0.512638 [Jacobsen, Wasserburg, 1980]. Величина $\varepsilon_{\mathrm{Nd}}$ на Земле гетерогенна и изменяется в пределах от -56 (древние гранитные массивы) до +12 (современные базальты срединноокеанических хребтов) [Jeandel et al., 2007]. В морской воде неодим в основном присутствует в растворенной форме (90 - 95\%, [Jeandel et al., 1995; Jeandel et al., 2007]).

Было показано, что гидротермальный источник неодима (содержание $\mathrm{Nd}$ в гидротермальном флюиде в 500-800 раз больше, чем в окружающей морской воде) не вносит значительного вклада в общую его концентрацию в морской воде, так как он извлекается гидротермальными минералами, формирующимися в непосредственной близости от устья гидротермы [German et al., 1990; Halliday et al., 1992]. Время пребывания его в гидротермальной системе составляет меньше одного года [Halliday et al., 1992].

Изучение медленнорастущих (1-10 мм/млн лет [Manheim, Lane-Bostwick, 1988]) железомарганцевых корок [van de Flierdt et al., 2006] и конкреций (ЖМК) [Albarede et al., 1997] показало, что они отражают изотопный состав неодима придонных вод, которые являются источником вещества для их формирования.. Однако изучение этих образований позволяет проследить рудоформирующую систему с разрешением в несколько миллионов лет. Более крупномасштабные вариации $\varepsilon_{\mathrm{Nd}}$ нашли свое отражение в гидротермальных образованиях, скорость накопления которых в 1000 раз больше [Clauer et al., 1984]. Было показано, что гидротермальные железомарганцевые корки Атлантического океана, как и гидрогенные, наследуют изотопный состав придонной морской воды со средним значением $\varepsilon_{\mathrm{Nd}}-12$, Однако незначительное присутствие гидротермальной составляющей способно резко повысить величину $\varepsilon_{\text {Nd. }}$ до -2, что отражает процентное содержание гидротермального флюида (99.71\%) и морской воды (0.29\%) в гидротермальных корках срединно-атлантического хребта [Mills et al., 2001].

Железомарганцевые образования задуговых бассейнов формируются в условиях интенсивной поставки терригенного вещества в среду седиментации. При интерпретации данных валового вещественного состава с целью определения генезиса этих образований могут возникнуть сложности. Наши предыдушие исследования показывают, что генетические критерии, разработанные для ЖМО открытой части океана, могут интерпретироваться ошибочно для ЖМО задуговых бассейнов [Михайлик и др., 2013]. Для уточнения источника поступления вещества, формирующего ЖМО Охотского моря, нами были изучены не только их химический и минеральный составы, но и изотопные характеристики неодима.

\section{МАТЕРИАЛ И МЕТОДЫ}

В Охотском море ЖМО приурочены в основном к подводным вулканическим возвышенностям Курильской островной дуги [Успенская и др., 1989; Glasby et al., 2006; Аникеева и др., 2008; Дубинин и др., 2008; Бутурин и др., 2012]. Они известны в 
центральной части моря, залегающие в пределах банки Кашеварова, возвышенности Академии наук, трога Кашеварова и хребта Зонне, а также глубоководных котловинах Дерюгина и Курильской [Штеренберг и др., 1987; Деркачев и др., 2002; Астахова, Саттарова, 2005; Михайлик и др., 2009; Иванова и др., 2019]. В связи с этим нами были выбраны образцы ЖМО с различных морфоструктурных элементов дна Охотского моря: 1 - ЖМО глубоководных котловин; 2 - ЖМО подводных гор и вулканов центральной части моря; 3 - ЖМО подводных вулканов Курильской островной дуги.

Отбор образцов ЖМО каждой группы, для последующего изучения изотопного состава $\mathrm{Nd}$, осуществлялся на основе банка данных минерального и химического состава ЖМО, полученных нами ранее (собственные неопубликованные данные). Пробы ЖМО Курильской островной дуги представлены образцами с максимальным и минимальным, а также медианным значением суммы редкоземельных элементов ( $\sum$ Р3Э). Образцы глубоководной котловины Дерюгина представлены как кольцеобразными конкрециями (KK), которые, в виде поясков окигидроксидов железа и марганца оконтуривают обломочной материал различного состава и размера, так и маломощными корками, формирующимися на верхней поверхности псефитового материала ледового разноса. Железомарганцевые корки хребта Зонне были выбраны как эталонные гидрогенные образования Охотского моря (Иванова и др., 2019). Детально вещественный состав образцов будет рассмотрен в соответствующих разделах.

Материалом для исследования послужили шесть образцов ЖМО (табл. 1, рис 1), отобранных в рейсах научно исследовательских судов «Академик М.А. Лаврентьев» (Lv54, Lv61), «Вулканолог» (В15, В17) и «Зонне» (SO178). В рейсах «Lv54» и «Lv61» визуализация геологических условий формирования КK в котловине Дерюгина (район «Баритовых гор») выполнялась с помощью телеуправляемого необитаемого подводного аппарата (ТНПА) «Comanch», а их пробоотбор производился дночерпателем «Океан-25». В рейсах B15, В17 и SO178 отбор ЖMO с подводных вулканов выполнялся драгированием.

Образцы ЖМО «Баритовых гор» на станции Lv54-41-3 (далее Lv54) представлены в виде колец сложенных черным рудным веществом, обрастающем по периметру гальку ледового разноса (рис 2а). Рыхлое железомарганцевое вещество толщиной около 5 мм образца Lv61-5 (далее Lv61) обрастает сверху окатанный обломок размером около 7 см (рис 2б). ЖМО Курильской островной дуги имеют иное строение. Образцы В15-25/4 и В17-43 представлены плотными корковыми разностями без субстрата (рис 2в, 2г). В строении ЖМО подводного Вулкана 7.14 (В17-43) на боковой поверхности темного цвета выделяются рыжие прослои и пятна (рис. 2г), по-видимому, сложенные железистыми оксигидроксидами. Образец, драгированный в пределах северного борта Курильской котловины с подводного вулкана Обручева (B17-11), представлен уплощенной пластиной толщиной около 2 см слаболитифицированой породы темно-серого цвета (рис. 2д). ЖМО хребта Зонне представлено светло-коричневой коркой, поднятой без субстрата толщиной около 4 см.

Для изучения валового минерального и химического, а также изотопного составов неодима отбиралась проба железомарганцевого вещества без субстрата массой 2 гр из верхнего слоя ЖМО. Производилось её истирание в яшмовой ступке до состояния пудры.

Минеральный состав ЖМО изучен методом порошковой дифрактометрии на рентгеновском дифрактометре MiniFlex II (Rigaku Corporation, Япония). Рентгенофазовый анализ был проведен с использованием $\mathrm{Cu}-\mathrm{K} \alpha$ излучения. Напряжение на рентгеновской трубке - 30кВ, ток трубки - 15мА. Непрерывная скорость сканирования составляла $1^{\circ}$ $2 \Theta /$ мин. Диапазон сканирования по углу $2 \Theta$ от 2.5 до $60^{\circ}$. На приборе также установлен $\mathrm{Ni}$ селективно поглощающий фильтр для подавления линий $\mathrm{K}_{\beta}$. Оценка качественного фазового состава была проведена с использованием базы данных ICDD 2010.

Валовый химический состав изучался рядом методов. С помощью метода ИСПАЭС определялись концентрации Ti, $\mathrm{Al}, \mathrm{Fe}, \mathrm{Mn}, \mathrm{Mg}, \mathrm{Ca}, \mathrm{Na}, \mathrm{K}, \mathrm{P}$, методом ИСП-МС 
определялись концентрации Li, Be, Sc, V, Cr, Co, Ni, Cu, Zn, Ga, As, Rb, Sr, Y, Zr, Nb, Mo, $\mathrm{Cd}, \mathrm{Cs}, \mathrm{Ba}, \mathrm{REE}, \mathrm{Hf}, \mathrm{Ta}, \mathrm{W}, \mathrm{Tl}, \mathrm{Pb}, \mathrm{Th}, \mathrm{U}$; определение содержания Si выполнено гравиметрическим методом.

Методом ИСП-АЭС измерения выполнены на спектрометре iCAP6500 Duo (Thermo Scientific, USA). Для градуировки прибора использовали многоэлементный сертифицированный раствор ICP MultiElementStandart IV (Merck, Германия). ИСП-МС анализ выполнялся на квадрупольном масс-спекторметреAgilent 7700x (AgilentTechnologies, Япония).Серию градуировочных растворов для ИСП-МС определения готовили весовым методом из многоэлементных стандартных растворов определяемых ионов. ИспользовалиMulti-element Calibration Standard 1 (№ 8500-6944), Multi-element Calibration Standard 2A (№ 8500-6940), Multi-element Calibration Standard 3 (№ 8500-6948) и Multi-element Calibration Standard 4 (№ 8500-6942) (Agilent Technologies, Япония). Оценка и контроль качества результатов анализа проб осуществлялись по стандартным образцам состава железомарганцевой конкреции: ООПЕ 601 (ГСО5373-90) и ООПЕ 602 (ГСО 5374-90).

Для выполнения ИСП анализа истёртый материал исследуемых проб предварительно высушивали при $105-110^{\circ} \mathrm{C}$ до постоянного веса. Высушенные пробы хранились в эксикаторе. Навески проб составляли 30 мг. Разложение проводили в платиновых чашках смесью концентрированных кислот $\mathrm{HF}, \mathrm{HNO}_{3}, \mathrm{HClO}_{4}$ («suprapur», Merck), кислоты приливали в отношении 3:5:1 мл, растворы упаривали при температуре $150-160^{\circ} \mathrm{C}$ до влажных солей. Повторно проводили обработку $\mathrm{HNO}_{3}$ и $\mathrm{HClO}_{4}$ в отношении 1:0.5 мл. Оксид марганца(IV), выделяющийся в процессе пробоподготовки, восстанавливали 26\%-ным раствором $\mathrm{HNO}_{3}$ с добавлением 35\%-ного раствора $\mathrm{H}_{2} \mathrm{O}_{2}$ («suprapur», Merck) при нагревании.

Выбранный способ пробоподготовки позволяет выполнить измерения концентраций как макрокомпонентов, так и микрокомпонентов из одного раствора

Устранение возможных полиатомных наложений выполнялось за счет аппаратного оформления процесса анализа. Так, при использовании квадрупольного массспектрометра Agilent 7700x, применялась столкновительная гелиевая ячейка, дающая возможность снизить интерференции на определяемых массах изотопов. Погрешность определения содержания микроэлементов не превышала 10-15\%, что хорошо согласуется с требованиями к определению содержания элементов на таком уровне [Кузнецова, Зарубина, 2004]. При анализе проб методом ИСП-АЭС контроль правильности и точности анализа осуществлялся при помощи стандартных образцов состава железомарганцевой конкреции. Существенных аналитических проблем при этом выявлено не было.

Изотопный состав Sm и Nd определялись методом изотопного разбавления. Масса навески пробы из каждого образца рассчитывалась из необходимого количества элемента в источнике ионов масс-спектрометра (300 нг $\mathrm{Nd}$ ). Таким образом, вес каждой пробы составил от 20 до 100 мг. Предварительно переведенные в хлоридную форму и высушенные пробы ЖМО взвешивались, к ним добавлялись смешанный трассер ${ }^{149} \mathrm{Sm}+{ }^{150} \mathrm{Nd}$ и 2 мл $6 \mathrm{~N} \mathrm{HCl}$. Смесь гомогенизировали и высушивали. Сухой остаток растворяли в 0.6 мл 2N HCl. Выделение проводилось методом ступенчатого элюирования: в 2N HCl выделялись породобразующие элементы, далее раствор менялся на $3.7 \mathrm{~N} \mathrm{HCl}$ для выделения суммы редкоземельных элементов на катионите Dowex AG W50x8 (200-400 меш). Извлечение $\mathrm{Nd}$ и $\mathrm{Sm}$ из порции элюата суммы редкоземельных элементов проводилось на колонках, заполненных Eichrom Ln.spec со ступенчатым элюированием $0.15 \mathrm{~N}, 0.30 \mathrm{~N} \mathrm{HCl}$ (выход $\mathrm{Nd}$ ) и $0.70 \mathrm{~N} \mathrm{HCl}$ (выход Sm). Причем предварительные исследования показали, что при стандартной схеме элюирования в порцию Nd попадает большое количество Ва (концентрация этого элемента в ЖМО достигает 0.5\% и более), который препятствует ионизации и ухудшает сигнал $\mathrm{Nd}$ при масс-спектрометрии. Поэтому был увеличен промывной объем первой стадии элюирования $0.15 \mathrm{~N} \mathrm{HCl}$ с 5 мл до 10 мл. Такой подход позволил практически полностью избавиться от Ва. Незначительные 
количества, которые попадали в пробу, выгорали при выходе на режим измерения $\mathrm{Nd}$. Полученные порции элюата выпаривались и в соответствующих пропорциях наносились на предварительно очищенные рениевые ленты. Масс-спектрометрическое измерение изотопного состава Sm и Nd проводились на многоколлекторном приборе Triton Plus (ЦКП «Геоаналитик», Екатеринбург). Для оценки инструментальной стабильности применяли международные стандарты LaJolla для $\mathrm{Nd}$. Отношение ${ }^{143} \mathrm{Nd} /{ }^{144} \mathrm{Nd}$ в стандарте во время работы составило 0.512758+/-0.000009 $(2 \sigma, \mathrm{n}=6)$. Изотопные отношения нормализовались по отношению ${ }^{146} \mathrm{Nd} /{ }^{144} \mathrm{Nd}=0.7219$. Погрешность измерения изотопного состава $\mathrm{Nd} \mathrm{в}$ индивидуальном анализе не превышало $0.005 \%$.

Все аналитические исследования в данной работе были выполнены в Центре коллективного пользования Дальневосточного геологического института ДВО РАН, а изотопный состав неодима в ЦКП «Геоаналитик», г. Екатеринбург.

\section{ГЕОЛОГИЧЕСКОЕ СТРОЕНИЕ}

Котловина Дерюгина является кайнозойским осадочным бассейном. Её дно расположено на глубине около 1800 м и покрыто голоценовыми кремнистыми осадками, относительно выдержанными по петрографическому, химическому составу и физическим свойствам, содержащий океанический комплекс диатомовой микрофлоры. Здесь же возвышаются на 200 - 300 м конические горы, которые предположительно могут являться недавно действовавшими вулканами. В СВ части котловины, где акустический фундамент постепенно поднимается в сторону банки Кашеварова, выявлены поднятия (холмы, банки и др.) с баритовой и карбонатной минерализацией («Баритовые горы», Клэм Хил и др.) [Cruise..., 2003; Dullo et al.,. 2004; Дальневосточные..., 2007; Геология..., 2011; Гранник и др., 2013].

Вулкан 1 хребта Зонне расположен на глубине 2500 м и возвышается над поверхностью дна примерно на 250 м. Эта вулканическая структура может быть представлена старым вулканическим конусом, который разрушился в результате взрывной вулканической активности или тектонических процессов [Dullo et al., 2004]. Склоны вулкана покрыты рыхлыми вулканокластическими образованиями, среди которых отмечаются небольшие выходы вулканических пород, представленных субщелочными клинопироксен-оливиновыми андезитами и клинопироксен-оливин-амфиболовыми базальтами [Тарарин, 2008].

Подводный вулкан 5.5 расположен в 20 км к северо-западу от северной оконечности о. Симушир, в 34 км от вулканического фронта. Это небольшая, довольно правильная коническая гора, поднимающаяся с глубины 1500 на 600 м. Она представляет собой существенно лавовый вулканический конус или купол. Эта структура сложена двупироксеновыми и клинопироксен-оливиновыми базальтами нормального ряда. На её склонах отсутствуют рыхлые отложения. Подводный вулкан 5.5 является молодым (вероятно плейстоценовым) вулканом [Подводный..., 1992].

Подводный вулкан 7.14 является составной частью подводного хребта западсеверо-западного простирания с тремя вершинами расположенного в 55-60 км к северу от п-ова Чирип (о. Итуруп), на расстоянии от 102 до 115 км от вулканического фронта. Хребет приурочен к Курильской глубоководной котловине, имеющей здесь глубину около 3300 м. Вершины имеют глубины от 1300 до 1600 м. Вулкан сложен амфиболовыми и пироксеновыми андезито-дацитами, а также андезито-базальтами. По уровню содержания щелочей амфиболовые разности относятся к высококалиевой серии субщелочного ряда, тогда как пироксеновые - к умеренно-калиевой серии нормального ряда. Осадки на склонах вулкана не фиксируются. Возраст хребта сравнительно древний (не менее 5 млн лет), хотя отдельные постройки могут быть и моложе [Подводный..., 1992].

Подводный вулкан Обручева, входящий в состав Броутонской группы подводных вулканов, расположен в 50 км к север-северо-западу от о. Броутона. Он возвышается над дном Охотского моря на 2200 м. По результатам драгирования, привершинную часть 
постройки, вероятно, слагают преобладающие в драгах островодужные пропилитизированные андезиты и дациандезиты, а также базальты умеренно-калиевой серии нормального ряда. Скорее всего, вулкан Обручева тоже имеет неогеновый возраст [Подводный..., 1992].

\section{РЕЗУЛЬТАТЫ И ОБСУЖДЕНИЕ}

Геологические условия залегания

Полученные данные с помощью ТНПА «Comanch» в 54-м и 61-м рейсах НИС «Академик М.А. Лаврентьев» при изучении геологических особенностей рудогенеза котловины Дерюгина показывают, что окраинноморская глубоководная фация оказалась наиболее благоприятной для формирования $\mathrm{Fe}-\mathrm{Mn}$ минерализации кольцеобразной морфологии. Здесь на поверхности дна выявлено большое количество различной степени окатанности псефитового материала покрытого Fe-Mn пленками и корками, опоясывающие субстрат. На мониторах в центре управления ТНПА они выглядят как многочисленные темно-коричневые и черные пятна и вкрапления на поверхности зеленовато-серых, светло-коричневых илов, а также отчетливо видимые черные обломки средних и крупных размеров галечного и щебневого материала, и, в редких случаях, валуны. Пробы грунта, взятые манипуляторами ТНПА и дночерпателями, подтвердили справедливость видеонаблюдений. Обломки, покрытые Fe-Mn пленками и корками различной конфигурации и толщины, варьируют в размерах по длинной оси от первых миллиметров до 40 - 50 см.

Визуальные наблюдения геологического строения Вулкана 1 (хребет Зонне) были выполнены с помощью буксируемого телевизионного аппарата «OFOS» в 178-м рейсе НИС «Зонне» (профиль So178-84-1). Результаты показали, что в пределах пути следования «OFOS» выявлены вулканокластические литифицированные породы, покрытые железомарганцевыми корками [Dullo et al., 2004]. Подводные вулканы Курильской островной дуги методами телевизионной визуализации изучены не были.

\section{Минералогия}

Результаты минераграфических исследований показывают, что образцы ЖМО котловины Дерюгина сложены смесью $10 \AA$ и $7 \AA$ манганитов, а также примесью кварца и плагиоклаза (рис. За, Зб). Минеральный состав ЖМО Вулкана 7.14 определен как $10 \AA$ тодорокит (?) (рис. Зв), Вулкана 5.5 - смесь вернадита и $10 \AA$ и $7 \AA$ манганитов (рис. Зг). Наиболее распространенным марганцевым минералом с $10 \AA$ рефлексом в ЖМО Курильской островной дуги является асболан (в большей степени отражающий диагенетическую поставку вещества), а преобладающим минералом является железистый вернадит [Успенская и др., 1989; Glasby et al., 2006; Батурин и др., 2012]. Минеральная смесь характерна и для ЖМО центральной части Охотского моря, где на фоне вернадитового состава, образцы содержат $10 \AA$ манганит [Михайлик и др., 2009]. Его присутствие объясняется локально происходящими диагенетическими процессами [Чухров и др., 1989]. В условиях высокой биопродуктивности поверхностных вод, имеющаяся в корках органика может локально восстанавливать марганец вернадитов до двухвалентного состояния, после чего будут происходить характерные диагенетические изменения с образованием $10 \AA$ манганитов. Корки хребта Зонне представлены вернадитом с незначительной примесью терригенного материала [Иванова и др., 2019].

По данным рентгеновской дифрактометрии (рис Зд) образец В17-11 представлен плагиоклазом в смеси с $10 \AA$ и $7 \AA$ манганитами, а также наличием аморфной фазы. Интенсивность пиков, соответствующих, марганцевым минералам (рис. Зд) указывает на значительное количество этих минералов в породе. Изучение шлифов показало, что это алевро-псамитовая вулканокластическая порода, пропитанная железомарганцевыми оксигидроксидами (рис 4). Основными кластами являются плагиоклазы (андезин) занимающие 20-25\% от общей площади шлифов, а также обломки пузыристого стекла 
часто растянутые. Встречаются призматические обломки пироксена и единичные зерна роговой обманки и, кроме того, радиолярии и обломки спикул губок. Такой морфотип ЖМО ранее в пределах Курильской островной дуги был выделен Т.Ю. Успенской с соавторами [1989].

\section{Химический состав ЖМО}

В табл. 2 показано содержание макро-, микро- и редкоземельных элементов, а также величины цериевой, европиевой аномалий и, кроме того, отношение концентраций иттрия к гольмию в изученных ЖМО.

Неоднородность состава ЖМО котловины Дерюгина выражена в концентрации марганца, которая отличается почти на 9\% (Lv61 - 22.6\% и Lv54 - 31.7\%), при близких содержаниях железа (Lv61 - 1.71\% и Lv54 - 1.28\%), что отражается на величине марганцевого модуля, который равен 13 и 25 для проб Lv61 и Lv54, соответственно (табл. 2). Такие значения модуля являются отражением различных условий роста этих ЖМО. Образец Lv54 формировался в условиях диагенеза в осадке, обогащенном Mn, относительно фоновых значений, в 35 раз [Астахов и др., 2007], а Lv61 в условиях придонной морской воды, где роль диагенеза ослабевает. Это как раз и выражается в уменьшении содержания марганца и увеличения железа (повышается доля гидрогенного вещества). Причем пропорциональные отношения $\mathrm{Mn}$ и Fe в этих двух пробах очень близки и составляют 1.40 и 1.33, соответственно.

Корковые разности КОД и хребта Зонне в своем составе имеют более низкие концентрации марганца от 9.55 до 16.8\%, а содержание железа в разы выше от 5.26 до $16.3 \%$ (табл. 2). Отношение марганца к железу сопоставимо с гидрогенными ЖМО и изменяется от 0.65 до 1.82 (табл. 2).

В осадках Охотского моря значительная примесь алюмосиликатного осадочного материала представлена продуктами ледового разноса [Wang et al., 2017] и кремнистым микропланктоном [Artemova et al., 2018] вследствие высокой биопродуктивности Охотского моря [Sorokin, Sorokin, 1999]. Количество кремния в осадках котловины Дерюгина в среднем составляет 29.1\% [Сатарова и др., 2013], в Курильской котловине 28.1\% [Sattarova, Aksentov, 2018]. Такие особенности седиментогенеза нашли свое отражение в концентрации кремния в «котловинных» ЖМО. В образце Lv61 его содержание составляет $18.2 \%$, а в Lv54 - 12.3\%. Для ЖМО, формирующихся в открытой части океана с минимальным седиментационным потоком, концентрация Si в среднем составляет 5.21\% [Hein et al., 2013]. Очевидно, что дополнительным источником кремнезема в ЖМО котловины Дерюгина служит интенсивный терригенный твердый сток и обилие кремниевой микрофауны. Наибольшее содержание кремния (23.4\%) установлено в пробе ЖМО с подводного вулкана Обручева, где основная часть кремнекислоты связана с вулканическим стеклом и плагиоклазом, а не с аморфным кремнеземом характерным для гидротермальных полей. K примеру, концентрация кремния в Si-Fe-Mn образования котловины Манус (гидротермальное поле ПАКМАНУС (PACMANUS)) составляет 21.731.4 \% [Yang et al., 2015], а количество марганца и железа изменяется от 7.06 до 10.8\% и 7.06 до 14.8\% [Zeng et al., 2012], соответственно. В остальных изученных нами ЖМО содержание Si варьирует от 12.3 до 18.2\% (табл. 2).

Наибольшая концентрация алюминия (5.8\%) установлена в ЖМО вулкана Обручева, что является отражением большого количества обломков плагиоклаза. В гидротермальных кремнистых образованиях концентрация алюминия не превышает $0.36 \%$ [Zeng et al., 2012], а в гидротермальных, не подвергшихся гидрогенному влиянию, ЖМО задуговых бассейнов его количество не превышает 1\% [Mikhailik et al., 2017]. Наименьшая концентрация Si (12.3\%) и $\mathrm{Al}$ (2.88\%) выявлена в KK (проба Lv54) котловины Дерюгина (табл. 2).

Таким образом, исходя из концентраций макроэлементов, можно сделать предположение предположить о наименьшем количестве терригенной примеси в пробе 
Lv54, которое выражается в наибольшей концентрации марганца и более низких концентрациях кремния и алюминия по отношению к другим исследованным пробам. Результаты изучения пробы В17-11 показывают, что основной массой пробы является вулканокластический материал, что влечет за собой увеличение концентраций кремния и алюминия. Повышенные содержания последнего характерны для ЖМО Курильской островной дуги [Дубинин и др., 2008].

Максимальная концентрация лития для пробы Lv54, равная 285 г/т (табл. 2), указывает на преимущественный диагенетический источник вещества за счет высокой биопродуктивности поверхностных вод и, как следствие, обилия органического вещества в поверхностных осадках, до 3.06\%, в среднем 1.53\% [Саттарова и др., 2013]. Такая закономерность выявлена в конкрециях, растущих в областях высокой биопродуктивности поверхностных вод в районе Перуанской котловины, содержащих 311 г/т лития [Hein et al., 2013]. В пределах экономической зоны островов Кука, где в осадках концентрация органического вещества незначительна его количество понижается до 51 г/т. [Hein et al.,

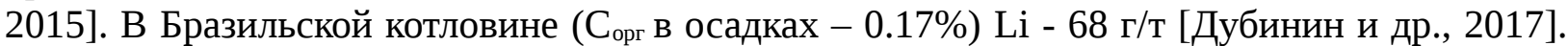
Концентрация лития в конкрециях зоны Кларион-Клиппертон составляет в среднем 129

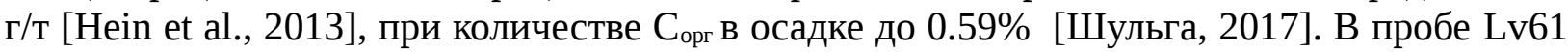
количество лития примерно в шесть раз меньше (58.3 г/т), чем в конкрециях Перуанской котловины, что, скорее всего, отражает значительное количество литогенного вещества. В ЖМО Курильской дуги его максимальная концентрация составляет 127 г/т в пробе В17-11, в которой выявлены минимальные содержания таких элементов индикаторов как кобальт, никель и медь (табл. 2). Исходя из минерального состава этой пробы, скорее всего, повышенное содержание лития является следствием гидротермальной пропитки, так как высокая концентрация этого элемента характерна для гидротермальных ЖМО Японского моря [Mikhailik et al., 2017], а также Западно-Тихоокеанской переходной зоны [Аникеева и др., 2008]. Уменьшение концентрации лития в других пробах ЖМО КОД (табл. 2) вместе с повышением содержания меди, никеля и кобальта свидетельствует об увеличении доли гидрогенного вещества в общей рудной массе ЖМО. А корки хребта Зонне характеризуются содержанием лития [Иванова и др., 2019] типичным для гидрогенных железомарганцевых образований открытой части океана [Hein et al., 2013].

Концентрация кобальта в ЖМО котловины Дерюгина мала (Lv54 - 47 г/т; Lv61 82.7 г/т), что свидетельствует об их высоких скоростях роста (в среднем 5.25 мкм/год, по кобальтовому хронометру по [Frank et al., 1999]), которые близки скоростям, вычисленным для ЖМО Балтийского моря (14-20 мкм/год, [Hlawatsch et al., 2002]) а также гидротермальных Fe-Mn корок окраинных морей [Михайлик и др., 2017]. В гидротермальных ЖМО вследствие высокой скорости их роста [Clauer et al., 1984] накопление кобальта, как в медленнорастущих гидрогенных ЖМО [Hein et al., 2000], не происходит. Типичные гидротермальные ЖМО, характеризуются концентрациями кобальта в пределах первых десятков г/т [Toth, 1980].

Железомарганцевые образования Охотского моря характеризуются более высокими концентрациями никеля чем ЖМО задуговых бассейнов и открытой части С-3 Пацифик [Батурин, 1993; Аникеева и др., 2002; Мельников; 2005; Дубинин и др., 2008; Иванова и др., 2019]. Высокие концентрации этого элемента (до 4800 г/т) наблюдаются в ЖМО центральной части Тихого океана [Usui et al., 1997], имеющих тодорокит-бёрнесситовый состав, характерный для низкотемпературных гидротермальных существенно марганцевых образований [Hein et al., 2008]. В поверхностных водах океана концентрация $\mathrm{Ni}$ низкая, а с увеличением глубины происходит обогащение вод никелем. Это связывают в первую очередь с его «биогенностью» [Bruland, 1980]. По своим биогенным свойствам Ni близок к другим биологически активным элементам, которые накапливаются планктоном в эвфотической зоне океана. Замечено [Sclater et al., 1976 Twining et al., 2012], что концентрация никеля закономерно возрастает с увеличением содержания таких нутриентов, как фосфор и кремний. В океане ведущую роль в биогеохимическом цикле 
никеля играют диатомеи, объем которых с увеличением широты возрастает, а в северных морях их количество максимально. По нашим данным, ЖМО, формирующиеся на подводных горах Охотского моря, характеризуются обилием остатков кремнистого микропланктона (рис. 5) [Михайлик, 2009]. Вследствие этого, высокие концентрации никеля в ЖМО вернадитового состава, являются результатом их формирования в районах с высокой биопродуктивностью.

\section{Геохимия РЗЭ}

Распределение нормализованных по сланцу (PAAS, [McLennan, 1989]) редкоземельных элементов (РЗЭ) и иттрия в «котловинных» пробах ЖМО показаны на рис. 6. Значение отрицательной цериевой аномалии (Cе $\left.\mathrm{C}_{\text {ан }}\right)$ пробы Lv54 равно 0.78, а проба Lv61 характеризуется положительным значением этой величины -1.24 . Такие значения указывает на различный механизм накопления церия в ЖМО котловины Дерюгина. Обычно, значения цериевой аномалии больше единицы наблюдаются в гидрогенных корках и конкрециях, а отрицательные в диагенетических конкрециях и гидротермальных корках. Отношения Ү/Но (иттриевая аномалия) в ЖМО различного генезиса отличается [Bau et al., 2014]. Установлено, что для гидрогенных и диагенетических разностей характерны значения этого отношения меньше 28, для гидротермальных и фосфтизированых корок (P > 0.7\%, [Koscinsky et al., 1997]) больше 28. Образец Lv61, имея положительную цериевую аномалию, указывающую на окислительную обстановку формирования ЖМО, характеризуется Y/Ho = 31, показывающим субвостановительные условия рудогенеза. Более того, в этой пробе установлена типичная для гидротермальных ЖМО [Bau et al., 2014] положительная европиевая аномалия ( $\left.\mathrm{Eu}_{\text {ан }}\right)$ равная 1.34 (табл. 2). Однако, её наличие, скорее всего, связано с примесью терригенного материала. Положительная $\mathrm{Eu}_{\text {ан }}$ в поверхностных окисленных осадках котловины Дерюгина является следствием присутствия довольно большого количества плагиоклаза в общем объеме пробы [Саттарова и др., 2014]. В условиях высоких скоростей осадконакопления в окраинных морях состав осадочного материала практически не подвергается изменению и наследует состав пород источников вещества на суше [Sholkovitz, 1992]. Основным источником терригенного материала в котловину Дерюгина является твердый сток р. Амур [Деркачев и др., 2004], в составе которого также выявлена положительная Еu $\mathrm{u}_{\text {aн }}$ [Сорокина, Зарубина, 2011]. Кроме того, величина европиевой аномалии зависит от соотношения количества диатомей и радиолярий, при увеличении последних $\mathrm{Eu}_{\text {aн }}$ растет. [Левитан и др., 2007].

Наличие отрицательной Се $\mathrm{e}_{\text {нн }}(0.78)$, положительной $\mathrm{Eu}_{\mathrm{aн}}(1.12)$ и отношение $\mathrm{Y} / \mathrm{Ho}=$ 22 в пробе Lv 54 свидетельствуют об отсутствии эндогенного влияния на формирование ЖМО. Эти данные согласуются с результатами изучения состава РЗЭ в баритовых постройках, которые показывают, что ведущая роль в формировании баритовой залежи принадлежит холодной газово-флюидной эманации, а гидротермальная составляющая на её формирование влияния не оказывает [Блохин и др., 2018].

Максимальная концентрация РЗЭ ( $Р$ РЭЭ = 1169 г/т) выявлена в корке хребта Зонне (табл. 2). Здесь состав РЗЭ проявлен в наличии положительной Се $_{\text {aн }}=1.81$,

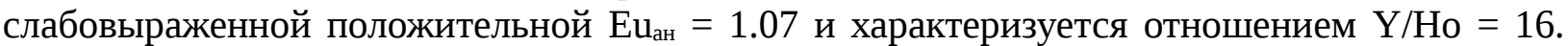
Нормализованный по сланцу (PAAS) состав РЗЭ показан на рис. 7. Близкими значениями концентрации, а также составом РЗЭ характеризуется образец с подводного Вулкана 7.14. В образце В17-43 сумма Р3Э немного меньше, однако, концентрация церия выше, что отразилось на величине цериевой аномалии, которая равна 2.86 (табл. 2). Европиевая аномалия, как и в образце So178, составляет 1.07, а Ү/Но отношение равно 19. Высокая концентрация церия в образце с подводного вулкана КОД, скорее всего, связана с более высокой концентрацией марганца. Ранее было показано, что окисление марганца, кобальта и церия в морской воде происходит при одинаковых условиях [Дубинин, 2006]. Поэтому 
для церия зависимость от содержания железа менее значима, чем для остальных РЗЭ и часть этого металла связывается с марганцевыми оксидами.

В образце с подводного Вулкана 5.5 наблюдается понижение величины цериевой аномалии до 1.35 и общей концентрации РЗЭ $(\Sigma$ Р3Э = 285 г/т) относительно ЖМО с Вулкана 7.14 и хребта Зонне. Значение отношения Ү/Но в пробе В15-25/4 составляет 21, а величина $\mathrm{Eu}_{\mathrm{aн}}=1.12$. Содержание кобальта и сумма РЗЭ указывают на высокую скорость

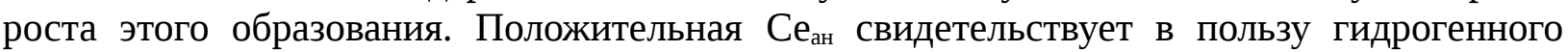
источника РЗЭ. По содержанию РЗЭ образец Вулкана 5.5 занимает промежуточное положение между котловинными конкрециями и корками подводных вулканов КОД. На диаграмме отношения значения цериевой аномалии к содержанию неодима (рис 8а) проба В15-25/4 тяготеет к гидрогенным образованиям, а на диаграмме взаимосвязи нормализованного по сланцу отношения Ү/Но и цериевой аномалии (рис. 8б) она попадает в нижнюю часть поля гидрогенных образований и тяготеет к области распространения смешанного типа ЖМО. Опираясь на тот факт, что образец был драгирован со склона молодого (четвертичного) вулкана, можно предположить, что его формирование протекало при смешении двух источников - гидротермального и гидрогенного, что привело к «промежуточному» составу РЗЭ между быстрорастущими КК в условиях окислительного диагенеза и гидрогенными железомарганцевыми корками подводных гор Охотского моря.

Таким образом, данные валового вещественного состава показывают, что четкую генетическую принадлежность проявляют два образца (B17-43 и So178) с ярко выраженными признаками гидрогенного рудонакопления. Остальные пробы не имеют четкой привязки к генезису, что является особенностью формирования ЖМО в условиях приконтинентального задугового литогенеза. Образец Lv54 в одном случае (рис. 8а) находится почти на границе диагенетических и гидротермальных образований, в другом (рис. 8б) на границе диагенетического и смешанного типа руд. Образец Lv61 не попал ни в одно генетическое поле, но тяготеет к гидротермальным образованиям (рис. 8а и 8б)

\section{Изотопный состав Nd}

Значение $\varepsilon_{\mathrm{Nd}}$ двух образцов, отобранных в непосредственной близости друг от друга в котловине Дерюгина, сильно отличаются. Для образца Lv61 оно составляет +1.2, для Lv54 - عNd = -1.8 (табл. 2). Положительное значение изотопного состава неодима в железомарганцевых образованиях встречается редко, вследствие того, что формирующиеся гидрогенным путем железомарганцевые оксигидроксиды сорбируют неодим из морской воды. Это приводит к тому, что гидрогенные корки и конкреции отражают изотопный состав неодима окружающей их морской воды, который характеризуется отрицательными значениями [Frank, 2002]. В результате подводной гидротермальной деятельности происходит температурная дифференциация флюида, поступающего в придонную морскую воду. Железомарганцевые образования отлагаются последними и могут накапливаться на значительных расстояниях от устья гидротермы. Вследствие того, что основная часть эндогенного неодима концентрируется веществом, формирующимся на начальных стадиях минералообразования, изотопный состав неодима в гидротермальных ЖМО отражает его значение в окружающей морской воде [Mills et al., 2001]. Изучение изотопного состава неодима гидротермальных железомарганцевых корок показало, что его изменения зависят от удаленности их формирования от места разгрузки гидротермы [Mills et al., 2001; Yang et al., 2015].

Глубоководные полиметаллические сульфиды, являющиеся первичным продуктом минеральной дифференциации гидротермального флюида в процессе смешения с морской водой, характеризуются более радиогенным изотопным составом неодима, близким к базальтам срединно-океанических хребтов [Hegner, Tatsumoto, 1987; Marques et al., 2006]. Повышение радиогенности изотопного состава неодима ранее наблюдались в металлоносных осадках при приближении к оси спрединга [Mills et al., 1995]. Положительные значения $\varepsilon_{\mathrm{Nd}}($ от +5.5 до +6.5) в задуговых бассейнах определены в Si-Fe- 
Mn образования котловины Манус [Yang et al., 2015] с содержанием кремния 21.7-31.4\%, образованных в непосредственной близости от выхода гидротермы. Гидротермальные сульфиды поля Рейнбоу слагающие трубы черных курильщиков и поддонное минералообразование характеризуются величиной $\varepsilon_{\mathrm{Nd}}$ от +5.6 до +8.7 [Marques et al., 2006].

Исходя из вышесказанного положительное значение $\varepsilon_{\mathrm{Nd}}$ образца Lv61 отражает присутствие в нем терригенной примеси (рис. За). Геохимические особенности формирования образца Lv54 указывают на участие поровых вод при его формировании. Поэтому изотопный состав неодима образца Lv54 может отражать величину $\varepsilon_{\text {Nd }}$ поровых вод поверхностного осадка котловины Дерюгина. Также значение $\varepsilon_{\mathrm{Nd}}=-1.8$ в пробе Lv54 может быть связано с дополнительным источником радиогенного неодима, высвобождаемого из наиболее подверженного гальмиролизу плагиоклаза [Дубинин, 2006].

Изотопный состав неодима $\left(\varepsilon_{\mathrm{Nd}}\right)$ в железомарганцевых корках подводного хребта Зонне составляет -3.2 , что близко его величине для вод северной Пацифики, которое равно -3.4 [Chen et al., 2011]. При приближении к Курильским островам, где повышается доля тихоокеанских вод, значение $\varepsilon_{\mathrm{Nd}}$ в гидрогенных корках Вулкана 7.14 понижается до -3.4, а в ЖМО Вулкана 5.5 оно повышается до -2.0. Такое повышение изотопного состава неодима может быть следствием умеренного разбавления гидротермального флюида, а также может отражать заражение вулканическими обломками, что приводит к повышению содержания титана и максимальному количеству из трех образцов ЖМО КОД таких элементов как хром, кальций и магний (табл. 2). Наибольшее значение $\varepsilon_{\mathrm{Nd}}(+4.4)$ установлено для ЖМО подводного вулкана Обручева. Выше мы уже указали, что эта проба представляет собой вулканомиктовый песчаник, пропитанный гидрооксидами Fe и $\mathrm{Mn}$, поэтому столь высокое значение не удивительно. Величина $\varepsilon_{\mathrm{Nd}}$ для пород подводного вулкана Обручева не известна, но в четвертичных лавах о. Броутона она составляет +8.2 [Martynov et al., 2007]. Следовательно, изотопный состав валовой пробы В17-11 представляет собой результат смешения алюмолисиликатного матрикса и железомарганцевого вещества.

\section{ЗАКЛЮЧЕНИЕ}

В процессе изучения ЖМО были выявлены закономерности, позволяющие по минеральному и химическому составу определить их генетический тип. Однако, минералого-геохимические критерии их разделения в основном были разработаны для ЖМО открытого океана. В областях приконтинентального литогенеза задуговых бассейнов, а также районов с активной вулканической деятельностью выявленные признаки для определенного генотипа ЖМО могут быть проявлены в другом генотипе. Это в свою очередь затрудняет определение генезиса и ведет к ошибочной интерпретации условий рудообразования.

Всесторонние минералогические, геохимические и изотопные исследования ЖМО Охотского моря и Курильской островной дуги позволили нам установить закономерности, которые напрямую отражают генетические аспекты их формирования. Геохимические особенности валового состава, а также изотопные характеристики неодима указывают на то, что идентификация ЖМО, сформировавшихся в условиях приконтинентального литогенеза является неоднозначной. Так, например, образец Lv54, сформировавшийся в условиях благоприятных для роста диагенетических ЖМО в котловине Дерюгина, также локализуется в районе предполагаемых гидротермальных эманаций [Астахов и др., 2017]. Хотя последние данные показывают, что в этом районе вероятность проявления гидротермальной активности является минимальной [Блохин и др., 2018]. Более того в представленном исследовании участвовали пробы (Lv61, B15-25/4, B17-11) с разной долей алюмосиликатной примеси, попавшей в бассейн седиментации, как с континента, так и за счет инситного разрушения вулканических построек. Не смотря на то, что минеральный состав довольно определенно свидетельствует об их генетическом типе, химические и 
изотопные данные валовых проб затрудняют классификацию. Это происходит за счет разубоживания проб алюминием и кремнием, привноса индикаторных редкоземельных элементов и смещения изотопного состава неодима. На данном этапе мы можем отнести пробу В15-25/4 к гидрогенному образованию, хотя изотопный состав неодима указывает на примесь эндогенного вещества. Образец Lv61 выбивается из всех существующих на данный момент классификационных признаков. Особенность его химического и изотопного состава заключается в том, что он имеет признаки всех генетических типов: гидрогенного, диагенетического и гидротермального. Можно предположить, что на формирование этого образца оказывали влияние разные источники вещества. Авторы склоняются к диагенетическому генезису при высокой доле литогенного материала.

Таким образом, на формирование ЖМО Охотского моря оказывают влияние, как терригенный сток, так и эндогенная составляющая, проявленная в гидротермальных поствулканических процессах, следствием которых является пропитка осадочных пород железомарганцевым веществом, а также формирование ЖМО в условиях возможных низкотемпературных эманаций в глубоководных котловинах.

Вся совокупность полученных данных и их интерпретация указывает на то, что необходимо сформировать иные подходы классификации ЖМО формирующихся в областях приконтинентального литогенеза, которые позволят учитывать значительное участие алюмосиликатной составляющей в этих образованиях.

Авторы выражают благодарность Капитану В.Б. Птушкину и экипажу 54-го и 61-го рейса НИС «Академик М.А. Лаврентьев», а также инженерному составу за слаженные действия и четкую организацию забортных работ, позволивших получить уникальный научный материал.

Научная экспедиция 54-го и 61-го рейсов НИС «Академик М.А. Лаврентьев» были выполнена при финансовой поддержке Президиума ДВО РАН.

Работа выполнена при финансовой поддержке грантов Российского научного фонда, проект № 18-17-00015 (определение валовых концентраций элементов), а также Российского фонда фундаментальных исследований, проектов №18-05-00436А (определение изотопного состава неодима) и 18-05-00410A (подготовка проб для проведения анализов).

\section{ЛИТЕРАТУРА}

1. Аникеева Л.И., Андреев С.И., Казакова В.Е., Александров П.А., Задорнов М.М. Кобальтбога-тые руды Мирового океана. СПб., ВНИИОкеангеология. 2002. 168 с.

2. Аникеева Л.И., Казакова В.Е., Гавриленко Г.М., Рашидов В.А. Железомарганцевые корковые образования Западно-тихоокеанской переходной зоны // Вестник КРАУНЦ. Науки о земле. 2008. №1. С. 10-31.

3. Астахов А.С., Ивин В.В., Карнаух В.Н. Карнаух В.Н., Коптев А.А., Ли Б.Я., Суховеев Е.Н. Современные геологические процессы и условия формирования баритовой залежи в котловине Дерюгина Охотского моря // Геология и геофизика. 2017. T. 58. № 2. С. 200-214.

4. Астахов А.С., Саттарова В.В., Свининников А.И., Астахова Н.В., Доианов М.М., Иванов М.В. Марганцевые металлоносные осадки котловины Дерюгина Охотского моря: химический состав, геологические условия формирования // Тихоокеанская геология. 2007. Т. 26, №5. С.13-31.

5. Астахова Н.В., Саттарова В.В. Геохимия железомарганцевых образований центральной части Охотского моря // Вулканология и сейсмология. 2005. № 3. С. 29-33.

6. Батурин Г.Н. Руды океанаю М., Наука. 1993. 303 к. 
7. Батурин Г.Н., Дубинчук В.Т., Рашидов В.А., Железомарганцевые корки Охотского моря // Океанология. 2012. Т.52, №1. С. 95-108.

8. Блохин М.Г., Ивин В.В., Михайлик П.Е., Михайлик Е.В., Иванова Ю.М., Еловский Е.В., Зарубина Н.В., Иванов В.В., Остапенко Д.С. Генезис баритов впадины Дерюгина (Охотское море) // Вестник КРАУНЦ. Науки о земле. 2018. Т.37. №1 С. 51-59.

9. Геология и минерагения дальневосточных морей России (твердые полезные ископаемые) / Тр. ВНИИОкеангеология. Т. 222. СПб.: ФГУП «ВНИИОкеангеология им. И.С. Грамберга», 2011. 126 с.

10. Гранник В.М., Литвинова А.В., Рудницкая Е.С., Ким А.Х. Кайнозойские осадочные бассейны Охотоморского региона: особенности строения и формирования / Тихоокеанская геология, 2013. Т. 32. № 2. С. 20-28.

11. Дальневосточные моря России (в 4 кн.). Книга 3. Геологические и геофизические исследования (гл. ред. Акуличев В.А.). М.: Наука, 2007. 503 с.

12. Деркачев А.Н., Тарарин И.А., Леликов Е.П., Можеровский А.В., Грайнерт Й., Баринов Н.Н. Проявление низкотемпературной гидротермальной деятельности в задуговом бассейне Охотского моря (Курильская глубоководная котловина) // Тихоокеанская геология. 2002. Т 21. № 3. С. 14-26.

13. Деркачев А.Н., Николаева Н.А., Горбаренко С.А. Особенности поставки и распределения кластогенного материала в Охотском море в позднечетвертичное время // Тихоокеанская геология. 2004. Т. 23, №1. С. 37-52

14. Дубинин А.В. Геохимия редкоземельных элементов в океане. М.: Наука. 2006. 360 c.

15. Дубинин А.В., Успенская Т.Ю., Гавриленко Г.М., Рашидов В.А. Геохимия и проблемы генезиса железомарганцевых образований островных дуг западной части Тихого океана // Геохимия. 2008. №12. С. 1280-1303.

16. Дубинин А. В., Успенская Т. Ю., Римская-Корсакова М. Н., Демидова Т. П. Редкие элементы и изотопный состав $\mathrm{Nd}$ и $\mathrm{Sr}$ в марганцевых микроконкрециях Бразильской котловины Атлантического океана // Литология и полезные ископаемые. 2017, № 2. С. 99-120

17. Иванова Ю.М., Михайлик П.Е., Михайлик Е.В., Зарубина Н.В., Блохин М.Г. Вещественный состав и условия формирования железомарганцевых корок хребта Зонне (Курильская котловина, Охотское море) // Геология и геофизика. 2019. Т. 60, №9. С. 1292-1309.

18. Кузнецова А. И., Зарубина О. В.. Оценка результатов атомно-эмиссионного анализа почв и донных грунтов по критериям качества, принятым в исследованиях в прикладной геохимии. // Аналитика и контроль. 2004. Т. 8, № 2. С. 144-151.

19. Левитан М.А., Лукша. В.Л., Толмачева А.В. История седиментации в северной части Охотского моря в течение последних 1.1 млн лет // Литология и полезные ископаемые. 2007. №3. С. 227-246.

20. Мартынов Ю.А., Кимура Дж.И., Ханчук А.И., Рыбин А.В., Чащин А.А., Мартынов А.Ю. Магматические источники четвертичных лав Курильской островной дуги: новые данные по изотопии стронция и неодима // ДОКЛАДЫ АКАДЕМИИ НАУК. 2007. Т. 416, № 5. С. 670-675.

21. Мельников М.Е. Месторождения кобальтоносных марганцевых корок. Геленджик, ФГУГП ГНЦ «Южморгеология», 2005, 230 с.

22. Михайлик П.Е. Состав, строение и условия формирования железомарганцевых корок Японского и Охотского морей. дис. канд. геол-минер. наук. ДВГИ ДВО РАН, Владивосток. 2009.

23. Михайлик П.Е., Деркачев А.Н., Чудаев О.В., Зарубина Н.В.. Железомарганцевые корки подводных возвышенностей трога Кашеварова (Охотское море) // Тихоокеанская геология. 2009. Т. 28. №1. С. 32-43. 
24. Михайлик П.Е., Михайлик Е.В., Зарубина Н.В., Блохин М.Г. Распределение редкоземельных элементов и иттрия в гидротермально-осадочных железомарганцевых корках Японского моря по результатам фазового анализа // Геология и геофизика. 2017. Т58, №12. С. 1928-1943.

25. Подводный вулканизм и зональность Курильской островной дуги. М.: Наука. 1992. 528 с.

26. Саттарова В. В., Астахов А. С., Колесник О. Н. Геохимические особенности поверхностного слоя донных отложений впадины Дерюгина Охотского моря // Геохимия. 2013. № 6. С. 529-540

27. Саттарова В.В., Зарубина Н.В., Блохин М.Г., Марьяш А.А. Редкоземельные элементы в поверхностных осадках впадины Дерюгина Охотского моря // Тихоокеанская геология. 2014. Т. 33, №2. С. 109-117

28. Сорокина О.А., Зарубина Н.В. Химический состав донных отложений среднего течения р. Амур // Тихоокеанская геология. 2011. Т. 30, №5. С. 105-113.

29. Тарарин И.А. Геологическое строение и модель формирования Курильской глубоководной впадины Охотского моря / Тихоокеанский Рудный Пояс: материалы новых исследований (гл. ред. Ханчук А.И.) // Владивосток: Дальнаука, 2008. С. 308320.

30. Успенская Т.Ю., Горшков А.И., Гавриленко Г.М., Сивцов А.В. Железомарганцевые корки и конкреции Курильской островной дуги: их строение, состав, генезис // Литология и полезные ископаемые. 1989. № 4. С. 30-40.

31. Чухров Ф.В., Горшков А.И., Дриц В.А. Гипергенные окислы марганца. М., Наука, 1989, 208 с.

32. Штеренберг Л.Е., Антипов М.П., Ильев А.Я., Александрова В.А., Сивцов А.В., Ильичева Л.В., Корина Е.А. Железомарганцевые образования Охотского моря // Изв. АН СССР. Сер. геол. 1987. № 12. С. 106-115.

33. Шульга Н.А. Особенности распределения Н-алканов в системе Fe-Mn конкрецииосадок-поровая вода (рудная провинция Кларион-Клиппертон) // Литология и полезные ископаемые. 2017. № 6. С. 11-17

34. Albarede F., Goldstein S.L., Dautel, D. The neodymium isotopic composition of manganese nodules from the Southern and Indian oceans, the global oceanic neodymium budget, and their bearing on deep ocean circulation // Geochimica et Cosmochimica Acta. 1997. V.61. N.6. P. 1277-1291.

35. Artemova A. V., Sattarova V. V., Vasilenko Y. P. Distribution of diatoms and geochemical features of holocene sediments from the Kuril Basin (Sea of Okhotsk) // Deep-Sea Research Part II. 2018. V. 154. P. 10-23.

36. Bau M., Koschinsky A. Oxidative scavenging of cerium on hydrous Fe oxide: Evidence from the distribution of rare earth elements and yttrium between Fe oxides and $\mathrm{Mn}$ oxides in hydrogenetic ferromanganese crusts // Geochemical Journal, 2009. V. 43. P. 37 47.

37. Bau M., Schmidt K., Koschinsky A. Hein J., Kuhn T., Usui A. Discriminating between different genetic types of marine ferro-manganese crusts and nodules based on rare earth elements and yttrium // Chemical Geology. 2014. V. 381. P. 1-9.

38. Bruland K. W. Oceanographic distributions of cadmium, zinc, nickel, and copper in the North Pacific // Earth and Planetary Science Letters 1980. V. 47. P. 176-198, doi:10.1016/0012-821X(80)90035-7.

39. Burton K. W., Vance D. Glacial-interglacial variations in the neodymium isotope composition of seawater in the Bay of Bengal recorded by planktonic foraminifera // Earth and Planetary Science Letters. 2000 V.176 P.425-441.

40. Byrne R.H. Inorganic speciation of dissolved elements in seawater: the influence of $\mathrm{pH}$ on concentration ratios //Geochem. Trans., 2002. V3, №2. P. 11-16. 
41. Chen T.Y., Ling H.F., Hu R. Neodymium isotopes distribution and transport in the central North Pacific deep water // Chinese Science Bulletin. 2011. V. 56. P. 2243-2250

42. Claude C., Suhr G., Hofmann A.W., Koschinsky A. U-Th chronology and paleoceanographic record in a Fe-Mn crust from the NE Atlantic over the last $700 \mathrm{ka} / /$ Geochimica et Cosmochimica Acta. 2005. V. 69. P. 4845-4854.

43. Clauer N., Stille P., Bonnot-Courtois C., Moore W.S. Nd-Sr isotopic and REE constraints on the genesis of hydrothermal manganese crusts in the Galapagos // Nature. 1984. V. 311. P. 743-745.

44. Cruise Report: KOMEX. RV Akademik M.A. Lavrentiev Cruise 29, Leg 1 and Leg 2 // GEOMAR Report, 110. Kiel. 2003. 190. 176 p.

45. Dullo W.-Chr., Biebow N., Georgeleit K. SO178-KOMEX Cruise Report. 2004. 125 p.

46. Frank M., O’Nions R. K., Hein J. R., Banakar V. K. 60 Myr records of major elements and $\mathrm{Pb}-\mathrm{Nd}$ isotopes from hydrogenous ferromanganese crusts: Reconstruction of seawater paleochemistry // Geochimica et Cosmochimica Acta. 1999. V. 63. P. 16891708.

47. Frank M. Radiogenic isotopes: tracers of past ocean circulation and erosional input // Reviews of Geophysics. 2002. V. 40. P. 1-38.

48. German, C. R., Klinkhammer G. P., Edmond J. M., Mitra A., Elderfield H., Hydrothermal scavenging of rare-earth elements in the ocean // Nature. 1990. V. 345. P. 516-518.

49. Glasby G.P., Cherkashov G.A., Gavrilenko G.M., Rashidov V.A., Slovtsov I.B. Submarine hydrothermal activity and mineralization on the Kurile and western Aleutian island arcs, N.W. Pacific // Marine Geology. 2006. V. 231. P.163-180

50. Gutjahr M., Frank M., Stirling C. H., Klemm V., van de Flierdt T., Halliday A. N. Reliable extraction of a deepwater trace metal isotope signal from Fe-Mn oxyhydroxide coatings of marine sediments // Chemical Geology. 2007. V. 242. P. 351-370.

51. Haley B.A., Klinkhammer G.P., McManus J. Rare earth elements in pore waters of marine sediments // Geochimica et Cosmochimica Acta. 2004. V. 68. P. 1265-1279.

52. Halliday, A. N., Davidson J. P., Holden P., Owen R. M., Olivarez A. M. Metalliferous sediments and the scavenging residence time of Nd near hydrothermal vents // Geophys. Res. Lett. 1992. V.19, P. 761-764.

53. Hegner E., Tatsumoto M. Pb, Sr, and Nd Isotopes in Basalts and Sulfides From the Juan de Fuca Ridge // Journal of geophysical research. 1987 V. 92. P. 11,380-11,386.

54. Hein J.R., Yeh H.W., Gunn S.H., Sliter W.V., Benninger L.M., Wang C.H. Two major Cenozoic episodes of phosphogenesis recorded in equatorial Pacific seamount deposits // Paleoceanography. 1993. V. 8, P. 293-311.

55. Hein, J.R., Koschinsky, A., Bau, M., Manheim, F.T., Kang, J.-K., Roberts, L., 2000. Cobalt-rich Ferromanganese Crusts in the Pacific. In: Cronan, D.S. (Ed.), Handbook of Marine Mineral Deposits. CRC Press, Boca Raton, Florida, pp. 239-279.

56. Hein J. R., Schulz M. S., Dunham R. E., Stern R. J., Bloomer S. H. Diffuse flow hydrothermal manganese mineralization along the active Mariana and southern Izu-Bonin arc system, western Pacific // Journal of geophysical research. 2008. V. 113 B08S14, doi:10.1029/2007JB005432

57. Hein, J.R., Mizell, K., Koschinsky, A., Conrad, T.A. Deep-oceanmineral deposits as a source of critical metals for high- and green-technology applications: comparison with land-based resources // Ore Geology Reviews. 2013. V. 51. P. 1-14.

58. Hein J. R., Spinardi F., Okamoto N., Mizell K., Thorburn D., Tawake A. Critical metals in manganese nodules from the Cook Islands EEZ, abundances and distributions // Ore Geology Reviews. 2015. V.68. P. 97-116.

59. Hlawatsch S., Garbe-Schönberg C.D., Lechtenberg F., Manceau A., Tamura N., Kulik D.A., Kersten M. Trace metal fluxes to ferromanganese nodules from the western Baltic 
Sea as a record for long-term environmental changes // Chemical Geology, 2002. Vol. 182. P. 697-709.

60. Horner T. J., Schönbächler M., Rehkämper M., Nielsen S. G., Williams H., Halliday A.N., Xue Z., Hein J. R. Ferromanganese crusts as archives of deep water Cd isotope Compositions // Geochemistry Geophysics Geosystems. 2010. V. 11. P. 1-10.

61. Ito T., Komuro K. Paleoceanographic Setting and Preservation of Buried Manganese Deposits in DSDP/ODP Cores // Resource Geology. 2006. V. 50. P. 457-470.

62. Jacobsen, S.B., Wasserburg, G.J. Sm-Nd isotopic evolution of chondrites // Earth Planet. Sci. Lett. 1980. V.50. P. 139-155.

63. Jeandel, C., Bishop, J.K., Zindler, A., Exchange of neodymium and its isotopes between seawater and small and large particles in the Sargasso Sea // Geochim. Cosmochim. Acta. 1995. V. 59P. 535-547.

64. Jeandel C., Arsouze T., Lacan F., Téchiné P., Dutay J.-C. Isotopic Nd compositions and concentrations of the lithogenic inputs into the ocean: A compilation, with an emphasis on the margins // Chemical Geology. 2007. V.239. P.156-164.

65. Jones K. M., Khatiwala S. P., Goldstein S. L., Hemming S. R., van de Flierdt T. Modeling the distribution of $\mathrm{Nd}$ isotopes in the oceans using an ocean general circulation model // Earth and Planetary Science Letters. 2008. V. 272. P. 610-619.

66. Koschinsky A., Halbach P., Hein J. R. Mangini Ferromanganese crusts as indicators for paleoceanographic events in the NE Atlantic // Geol Rundsch. 1996. V. 85. P. 567-576.

67. Manheim F.T., Lane-Bostwick C.M. Cobalt in ferromanganese crusts as a monitor of hydrothermal discharge on the Pacific seafloor // Nature. 1988. V. 335. P. 59-62.

68. Marques A. F. A., Barriga F., Chavagnac V., Fouquet Y. Mineralogy, geochemistry, and Nd isotope composition of the Rainbow hydrothermal field, Mid-Atlantic Ridge // Miner Deposita. 2006. V. 41. P. 52-67

69. McLennan S. M. Rare earth elements in sedimentary rocks: influence of provenance and sedimentary processes // (Lipin, B. R. and McKay, G. A., eds.) Geochemistry and Mineralogy of the Rare Earth Elements / 1989. Rev. Mineral. 21. P. 169-200.

70. Mills R.A., Elderfield H. Rare earth element geochemistry of hydrothermal deposits from the active TAG Mound, $26^{\circ} \mathrm{N}$ Mid-Atlantic Ridge // Geochimica et Cosmochimica Acta.. 1995. V. 59. N. 17. P. 3511-3524.

71. Mills R.A., Wells D.V., Roberts S. Genesis of ferromanganese crusts from the TAG hydrothermal field // Chemical Geology. 2001. V. 176. P. 283-293.

72. Nielsen S. G., Mar-Gerrison S., Gannoun A., LaRowe D., Klemm V., Halliday A. N., Burton K. W., Hein J. R. Thallium isotope evidence for a permanent increase in marine organic carbon export in the early Eocene // Earth and Planetary Science Letters. 2009. V. 278. P. 297-307.

73. Piotrowski A. M., Goldstein S. L., Hemming S. R., Fairbanks R. G. Temporal Relationships of Carbon Cycling and Ocean Circulation at Glacial Boundaries // Science. 2005. V. 307. P. 1933-1938.

74. Roberts N. L., Piotrowski A. M., McManus J. F., Keigwin L. D. Synchronous Deglacial Overturning and Water Mass Source Changes // Science. 2010. V. 327. P. 75-78.

75. Sattarova V. V., Aksentov K. I. Geochemistry of mercury in surface sediments of the Kuril Basin of the Sea of Okhotsk, Kuril-Kamchatka Trench and adjacent abyssal plain and northwest part of the Bering Sea // Deep-Sea Research Part II. 2018. V. 154. P. 24-31

76. Sclater F. R., Boyle E., Edmond J. M. On the marine geochemistry of nickel // Earth Planet. Sci. Lett. 1976. V.31. P. 119-128, doi:10.1016/ 0012-821X(76)90103-5.

77. Siddall M., Khatiwala S., van de Flierdt T., Jones K., Goldstein S. L., Hemming S., Anderson R. F. Towards explaining the Nd paradox using reversible scavenging in an ocean general circulation model // Earth and Planetary Science Letters. 2008. V. 274. P. 448-461. 
78. Sorokin Yu. I., Sorokin P.Yu. Production in the Sea of Okhotsk // Journal of Plankton Research. 1999. V. 21. P. 201-230.

79. Toth J.R. Deposition of submarine crusts rich in manganese and iron // Geological Society of America Bulletin. 1980. V. 91. P. 44-54.

80. Twining B. S., Baines S. B., Vogt S., Nelson D. M. Role of diatoms in nickel biogeochemistry in the ocean // Global biogeochemical cycles. 2012. V. 26 GB4001, doi:10.1029/2011GB004233

81. Usui A., Bau M., Yamazaki T. Manganese microchimneys buried in the Central Pacific pelagic sediments: evidence of intraplate water circulation? // Marine geology. 1997. V. 141. P. 269-285.

82. Usui A., Graham I. J., Ditchburn R. G., Zondervan A., Shibasaki H., Hishida H. Growth history and formation environments of ferromanganese deposits on the Philippine Sea Plate, northwest Pacific Ocean // Island Arc. 2007. V. 16. P. 420-430.

83. van de Flierdt T., Frank M, Halliday A. N., Hein J. R., Hattendorf B., Günther D., Kubik P. W. Lead isotopes in North Pacific deep water - implications for past changes in input sources and circulation patterns // Earth and Planetary Science Letters. 2003. V. 209. P. 149-164.

84. van de Flierdt T., Hemming S. R., Goldstein S. L., Abouchami W. Radiogenic isotope fingerprint of Wilkes Land-Adélie Coast Bottom Water in the circum-Antarctic Ocean // Geophysical research letters, 2006, V. 33. P. 1-5.

85. Wang K. S., Shi X. F., Zou J. J., Kandasamy S., Gong X., Wu Y. H., Yan Q. S. Sediment provenance variations in the southern Okhotsk Sea over the last $180 \mathrm{ka}$ : Evidence from light and heavy minerals // Palaeogeography, Palaeoclimatology, Palaeoecology. 2017. V. 479. P. 61-70.

86. Yang B., Zeng Z., Wang X. Characteristics of Sr, Nd and Pb isotopic compositions of hydrothermal Si-Fe-Mn-oxyhydroxides at the PACMANUS hydrothermal field, Eastern Manus Basin // Acta Oceanol. Sin. 2015. V. 34. P. 27-34.

87. Zeng Z., Ouyang H., Yin X., Chen S., Wang X., Wu L. Formation of Fe-Si-Mn oxyhydroxides at the PACMANUS hydrothermal field, Eastern Manus Basin: Mineralogical and geochemical evidence // Journal of Asian Earth Sciences. 2012. V. 60. P. 130-146. 


\section{Подписи к рисункам}

Рис. 1. Места отбора проб: Lv54, Lv61 - Котловина Дерюгина; SO178-5-4 - хребет Зонне; В17-43 - Вулкан 7.14; В17-11 - вулк. Обручева; В15-25/4 - Вулкан 5.5.

Рис. 2. Внешний вид образцов железомарганцевых образований: A - Lv54; Б - Lv61; В В15-25/4; Г - В17-43; Д - В17-11; E - SO178-5-4.

Рис. 3. Дифрактограммы образцов.

Котловина Дерюгина:

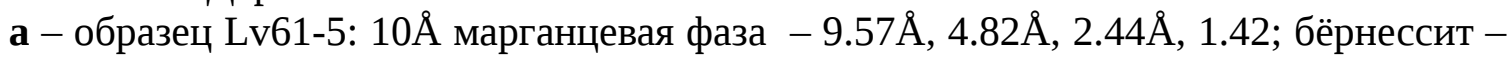

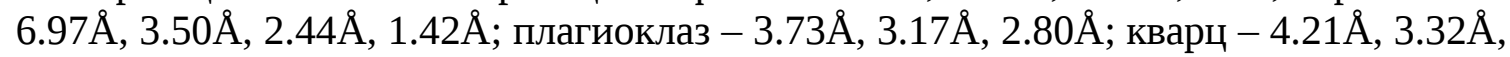
2.12A, $1.98 \AA, 1.81 \AA, 1.67 \AA, 1.53 \AA, 1.37 \AA$;

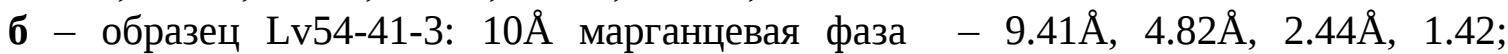

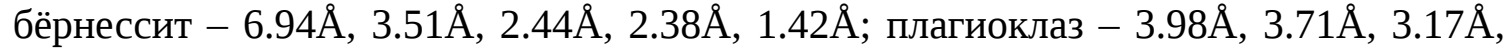

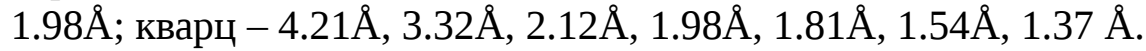

Курильская островная дуга:

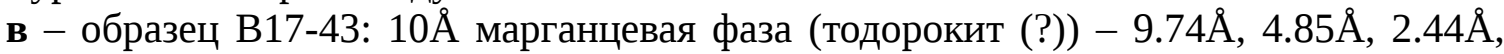

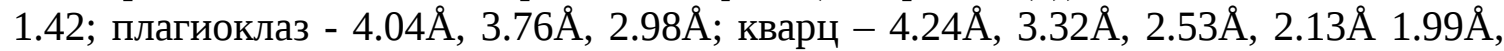
$1.82 \AA, 1.62 \AA, 1.49 \AA, 1.39 \AA$

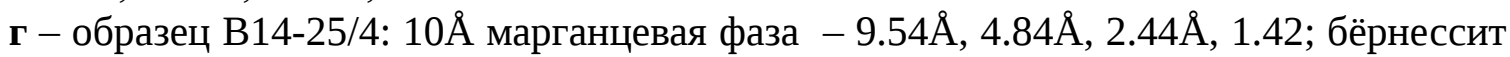

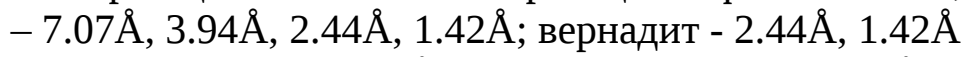

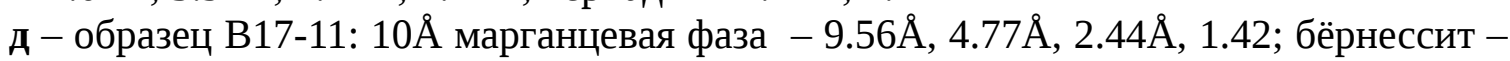

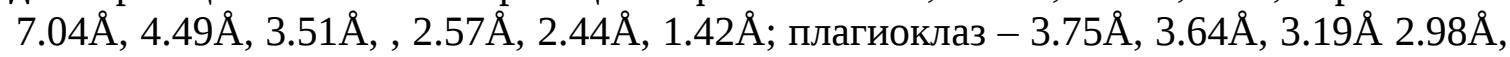
$2.13 \AA \AA$.

Рис. 4. Шлиф (николи параллельно, х100) образца В17-11, алеврито-псамитовая вулканокластическая порода, пропитанная железомарганцевыми окигидроксидами.

Рис. 5. Органические остатки в железомарганцевых образованиях Охотского моря [Михайлик, 2009].

Рис. 6. Состав нормализованных по сланцу (PAAS, [McLennan, 1989]) редкоземельных элементов кольцеобразных конкреций котловины Дерюгина.

Рис. 7. Состав нормализованных по сланцу (PAAS, [McLennan, 1989]) редкоземельных элементов железомарганцевых образований хребта Зонне и Курильской островной дуги.

Рис. 8. Положение результатов химического анализа железомарганцевых образований Охотского моря и Курильской островной дуги в координатах: A - $\mathrm{Ce}_{\mathrm{SN}} / \mathrm{Ce}_{\mathrm{SN}} *-\mathrm{Nd}$; Б

$-\mathrm{Ce}_{\mathrm{SN}} / \mathrm{Ce}_{\mathrm{SN}} *-\mathrm{Y}_{\mathrm{SN}} / \mathrm{Ho}_{\mathrm{SN}}$ 
Таблица 1. Координаты, глубина и место отбора проб ЖМО

\begin{tabular}{|r|c|c|c|c|c|c|}
\hline $\begin{array}{r}\text { № } \\
\text { п/п }\end{array}$ & № образца & Широта, с.ш. & Долгота, в.д. & Глубина, м & Рейс, год & Местоположение \\
\hline 1 & Lv54-41-3 & $54^{\circ} 00.396$ & $146^{\circ} 25.551$ & 1437 & $\mathrm{Lv} 54,2011$ & Баритовые горы \\
\hline 2 & $\mathrm{Lv} 61-5$ & $54^{\circ} 00.617$ & $146^{\circ} 25.467$ & 1450 & $\mathrm{Lv} 61,2013$ & Баритовые горы \\
\hline 3 & $\mathrm{~B} 15-25 / 4$ & $47^{\circ} 20.8^{\prime}$ & $152^{\circ} 05.6^{\prime}$ & $960-1250$ & $\mathrm{~B} 15,1982$ & Вулкан 5.5 \\
\hline 4 & $\mathrm{~B} 17-43$ & $46^{\circ} 01.0^{\prime}$ & $147^{\circ} 56.2^{\prime}$ & $1650-1500$ & $\mathrm{~B} 17,1983$ & Вулкан 7.14 \\
\hline 5 & В17-11 & $47^{\circ} 07.3^{\prime}$ & $150^{\circ} 28.9^{\prime}$ & $1240-1140$ & B17, 1983 & вулк. Обручева \\
\hline 6 & SO178-5-4 & $47^{\circ} 54.02^{\prime}$ & $147^{\circ} 49.11^{\prime}$ & $2346-2201$ & SO178, 2004 & $\begin{array}{c}\text { Хребет Зонне, } \\
\text { Вулкан } 1\end{array}$ \\
\hline
\end{tabular}


Таблица 2. Химический состав железомарганцевых образований Охотского моря и Курильской островной дуги.

\begin{tabular}{|c|c|c|c|c|c|c|}
\hline & LV 61-5 & Lv54-41-3 & В $17-11 / 1$ & B15-25/4 & В $17-43$ & So $178-5-4-2$ \\
\hline Si (\%) & 18.2 & 12.3 & 23.4 & 15.8 & 15.5 & 18.0 \\
\hline $\mathrm{Ti}$ & 0.16 & 0.1 & 0.27 & 0.53 & 0.29 & 0.25 \\
\hline $\mathrm{Al}$ & 4.06 & 2.88 & 5.80 & 5.51 & 3.23 & 3.03 \\
\hline $\mathrm{Fe}$ & 1.71 & 1.28 & 5.26 & 9.38 & 11.2 & 16.3 \\
\hline Mn & 22.6 & 31.7 & 9.55 & 14.8 & 16.8 & 10.7 \\
\hline $\mathrm{Mg}$ & 0.85 & 1.04 & 1.40 & 2.39 & 1.31 & 0.76 \\
\hline $\mathrm{Ca}$ & 1.98 & 1.87 & 2.56 & 3.85 & 1.62 & 1.73 \\
\hline $\mathrm{Na}$ & 3.61 & 3.02 & 2.93 & 2.16 & 2.07 & 2.16 \\
\hline $\mathrm{K}$ & 1.25 & 1.05 & 1.41 & 0.70 & 1.24 & 0.84 \\
\hline $\mathrm{P}$ & 0.05 & 0.04 & 0.09 & 0.16 & 0.26 & 0.28 \\
\hline ппп & 10.4 & 11.3 & 6.16 & 7.79 & 10.5 & 8.66 \\
\hline $\operatorname{Li}(\Gamma / \mathrm{T})$ & 58.3 & 285 & 127 & 94.6 & 28.4 & 5.02 \\
\hline $\mathrm{Be}$ & 0.67 & 0.5 & 0.04 & 0.86 & 2.24 & 2.59 \\
\hline Sc & 6.67 & 3.94 & 0.19 & 22.6 & 12.1 & 10.5 \\
\hline V & 207 & 258 & 19.3 & 501 & 460 & 385 \\
\hline $\mathrm{Cr}$ & 29.7 & 16.2 & 5.98 & 43.2 & 37.8 & 17.8 \\
\hline Co & 82.7 & 47.1 & 20.8 & 360 & 665 & 444 \\
\hline $\mathrm{Ni}$ & 600 & 821 & 27.7 & 2041 & 4205 & 1243 \\
\hline $\mathrm{Cu}$ & 55.9 & 74.9 & 3.36 & 225 & 425 & 220 \\
\hline $\mathrm{Zn}$ & 419 & 608 & 15.8 & 985 & 728 & 370 \\
\hline $\mathrm{Ga}$ & 10.9 & 13.1 & 1.49 & 9.17 & 15.3 & 10.7 \\
\hline As & 15.9 & 20.1 & 77.3 & 61.3 & 144 & 178 \\
\hline $\mathrm{Rb}$ & 31 & 22.7 & 11.1 & 15.1 & 33.2 & 24.1 \\
\hline $\mathrm{Sr}$ & 406 & 466 & 959 & 539 & 804 & 852 \\
\hline Y & 18.5 & 18.2 & 10.1 & 43.4 & 85.9 & 104 \\
\hline $\mathrm{Zr}$ & 36.7 & 23.2 & 2.91 & 86.8 & 234 & 387 \\
\hline $\mathrm{Nb}$ & 2.67 & 1.4 & 0.1 & 4.49 & 14.1 & 16.6 \\
\hline Mo & 423 & 363 & 57.7 & 251 & 422 & 240 \\
\hline $\mathrm{Cd}$ & 3.43 & 11.3 & 0.46 & 8.69 & 8.89 & 2.82 \\
\hline $\mathrm{Ba}$ & 1733 & 2680 & 1096 & 1201 & 2348 & 1168 \\
\hline Cs & 1.12 & 0.92 & 0.64 & 0.84 & 1.57 & 1.05 \\
\hline $\mathrm{La}$ & 13.9 & 14.9 & 2.47 & 42.4 & 111 & 149 \\
\hline Ce & 36.6 & 25 & 3.49 & 129 & 717 & 626 \\
\hline $\operatorname{Pr}$ & 3.32 & 3.68 & 0.45 & 11.5 & 29.9 & 42.1 \\
\hline Nd & 13 & 16.1 & 1.93 & 48.5 & 122 & 175 \\
\hline Sm & 2.89 & 3.4 & 0.4 & 11.6 & 29.1 & 39.1 \\
\hline Eu & 0.87 & 0.89 & 0.1 & 2.81 & 6.51 & 9.1 \\
\hline Gd & 3.19 & 4.02 & 0.55 & 11.9 & 28.1 & 40.3 \\
\hline $\mathrm{Tb}$ & 0.46 & 0.62 & 0.08 & 1.8 & 4.16 & 6.18 \\
\hline Dy & 2.81 & 4.02 & 0.55 & 10.2 & 22.7 & 35.3 \\
\hline Но & 0.59 & 0.83 & 0.16 & 2.04 & 4.41 & 6.52 \\
\hline Er & 1.86 & 2.49 & 0.53 & 5.59 & 12.1 & 18.7 \\
\hline $\mathrm{Tm}$ & 0.25 & 0.36 & 0.09 & 0.8 & 1.74 & 2.49 \\
\hline $\mathrm{Yb}$ & 1.76 & 2.4 & 0.59 & 5.16 & 11.2 & 16.7 \\
\hline $\mathrm{Lu}$ & 0.24 & 0.37 & 0.12 & 0.76 & 1.76 & 2.45 \\
\hline Hf & 0.81 & 0.08 & 0.04 & 1.62 & 3.55 & 6.76 \\
\hline $\mathrm{Ta}$ & 0.11 & 0.01 & 0.01 & 0.15 & 0.33 & 0.18 \\
\hline W & 20.1 & 112 & 65.2 & 30.4 & 52.3 & 31.6 \\
\hline $\mathrm{Tl}$ & 4.24 & 12.5 & 0.15 & 13.2 & 81.1 & 32.9 \\
\hline \multicolumn{7}{|c|}{ Окончание таблицы } \\
\hline $\mathrm{Pb}$ & 19.2 & 7.37 & 1.25 & 72.8 & 466 & 495 \\
\hline
\end{tabular}




$\begin{array}{ccccccc}\mathrm{Th} & 1.65 & 1.57 & 0.04 & 4.69 & 22.9 & 40.1 \\ \mathrm{U} & 1.5 & 7.19 & 7.45 & 2.4 & 4.87 & 7.44 \\ \mathrm{Mn} / \mathrm{Fe} & 13 & 25 & 1.82 & 1.57 & 1.51 & 0.65 \\ \mathrm{Co}+\mathrm{Ni}+\mathrm{Cu} & 739 & 943 & 51.9 & 2626 & 5295 & 1907 \\ \Sigma \mathrm{P} 3 \ni & 82 & 79 & 12 & 285 & 1102 & 1169 \\ \mathrm{Ce} * & 1.24 & 0.78 & 0.76 & 1.35 & 2.86 & 1.81 \\ \mathrm{Eu} * & 1.34 & 1.12 & 0.97 & 1.12 & 1.07 & 1.07 \\ \mathrm{Y} / \mathrm{Ho} & 31 & 22 & 63 & 21 & 19 & 16 \\ (\mathrm{Y} / \mathrm{Ho})^{*} & 1.11 & 0.78 & 2.23 & 0.75 & 0.69 & 0.56 \\ \varepsilon_{\mathrm{Nd}} & +1,17 & -1,83 & +4,4 & -2 & -3,4 & -3,2\end{array}$




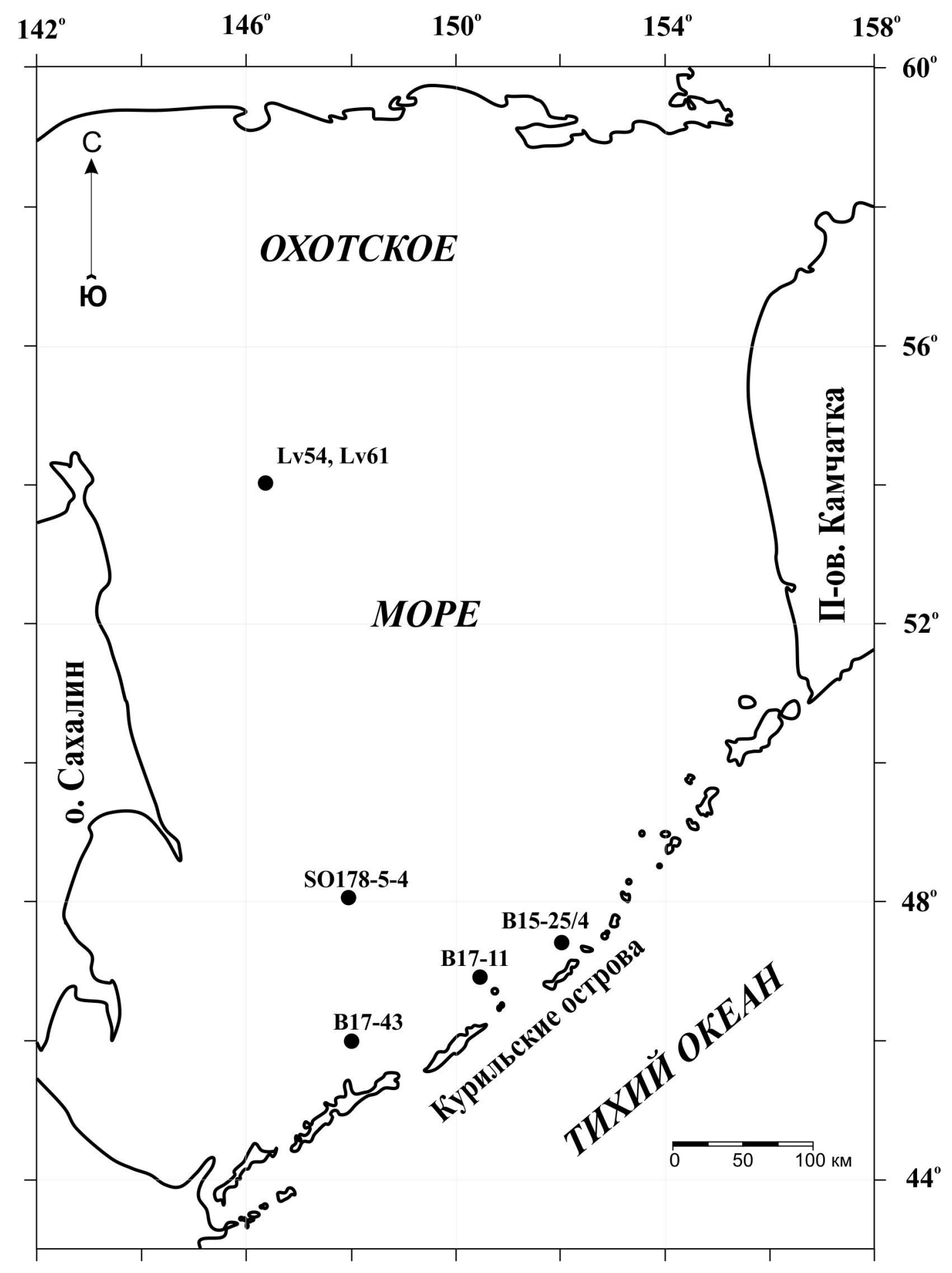



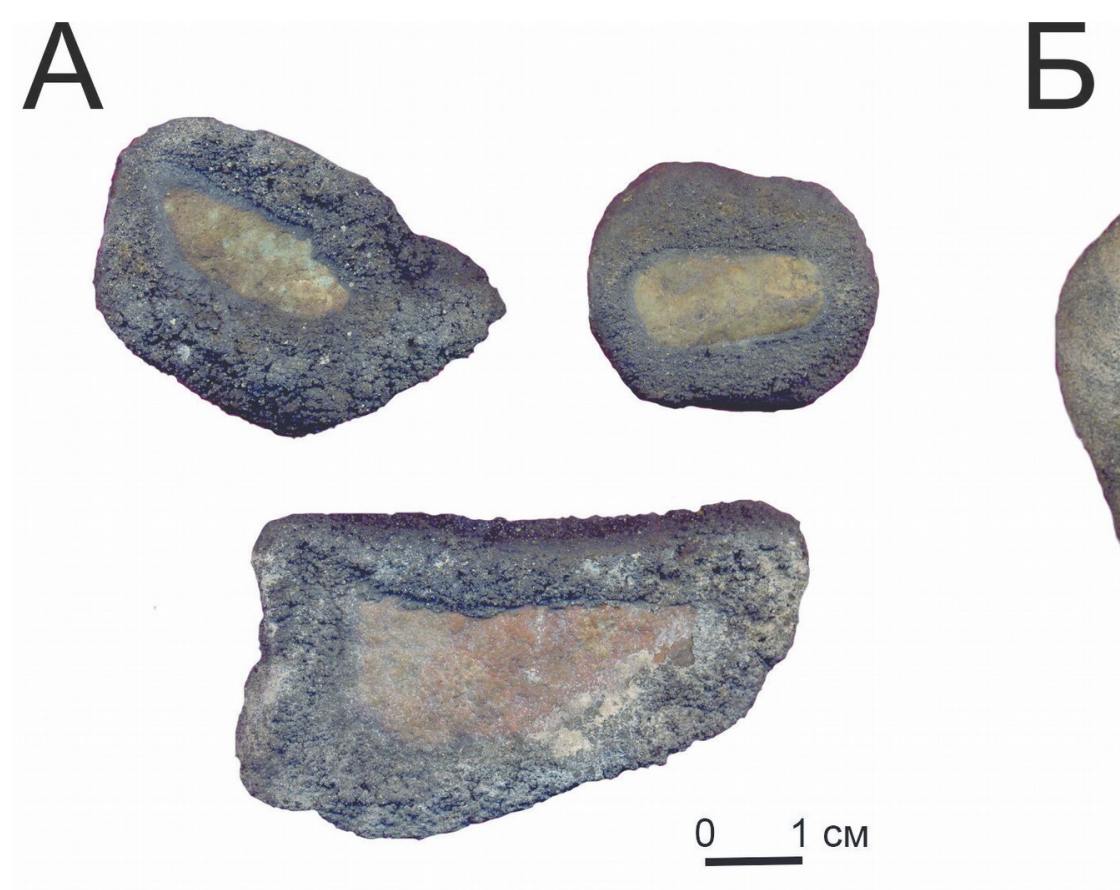

B
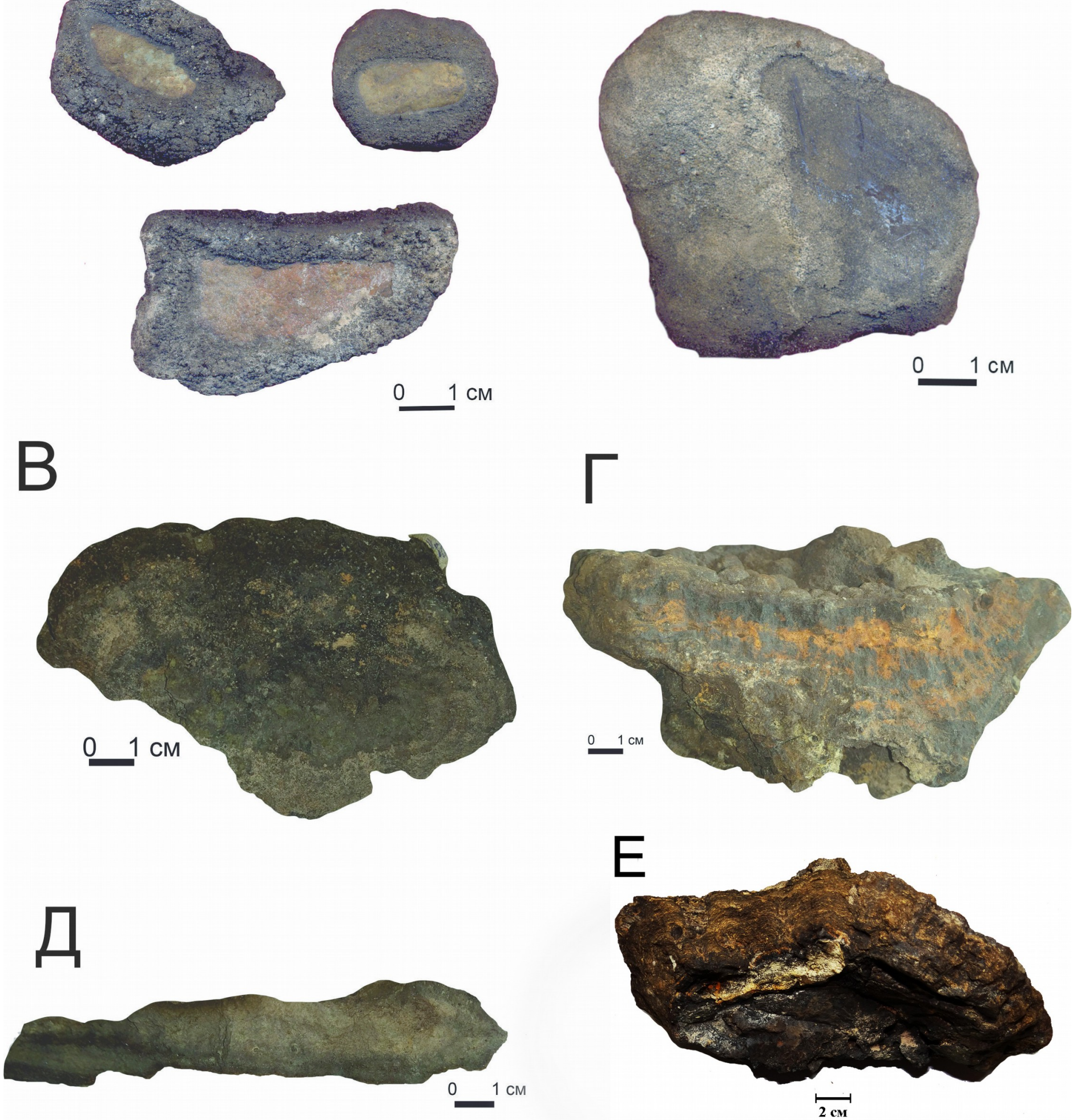


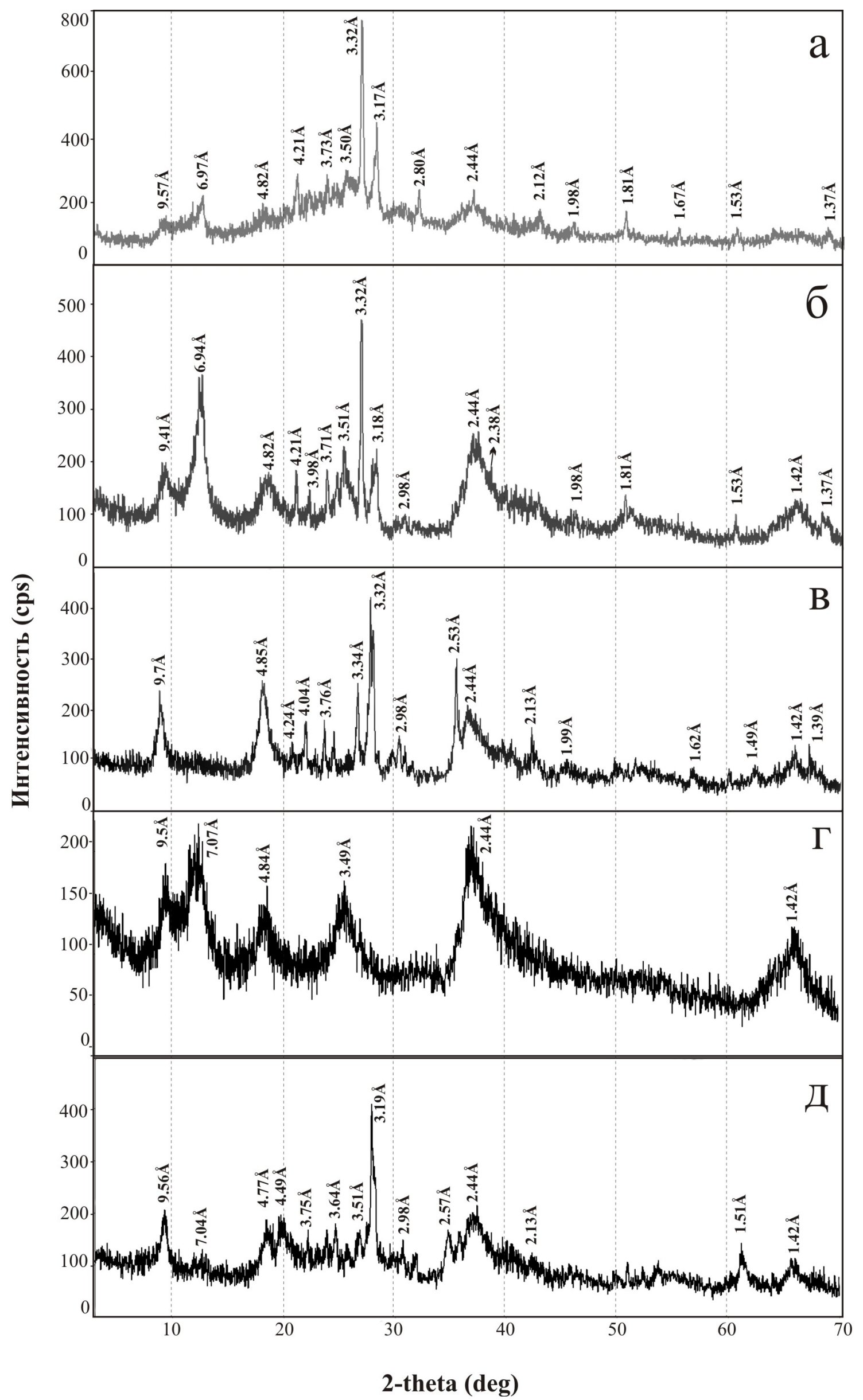




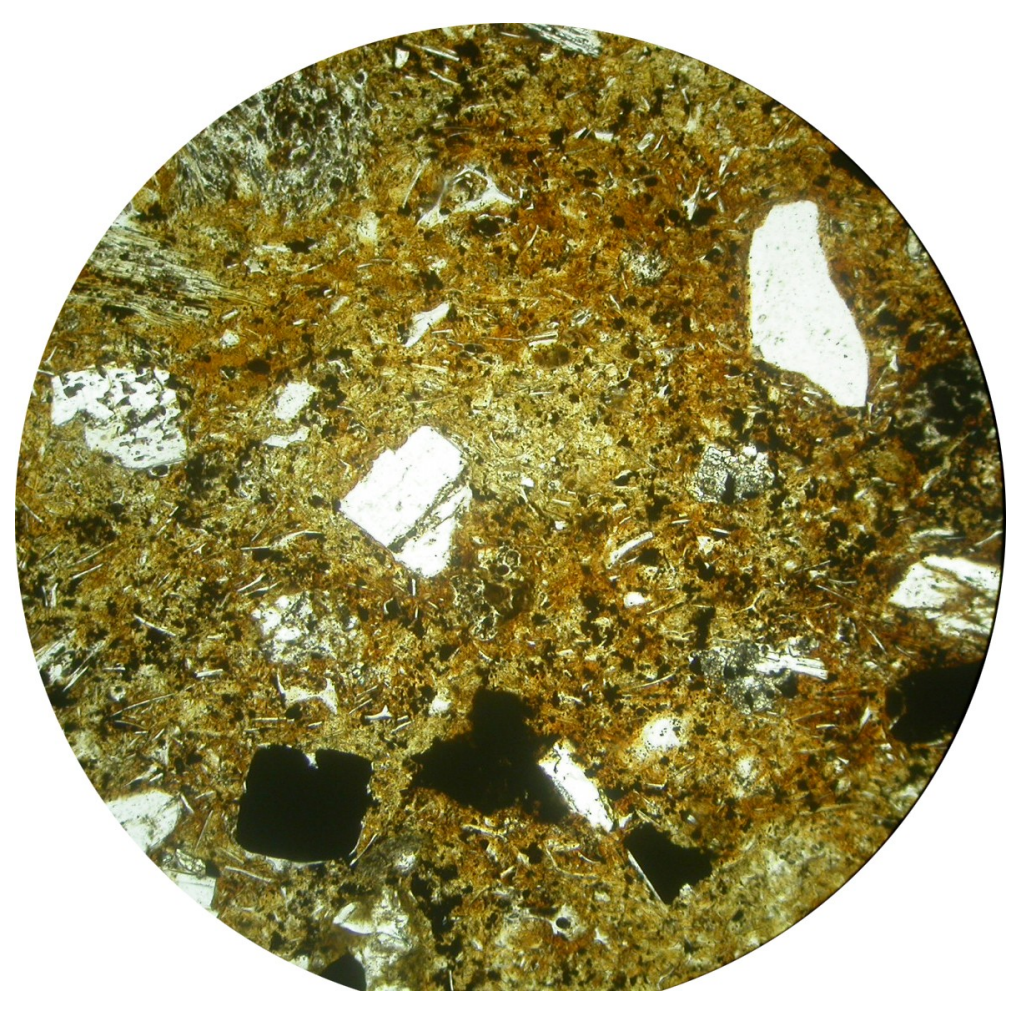



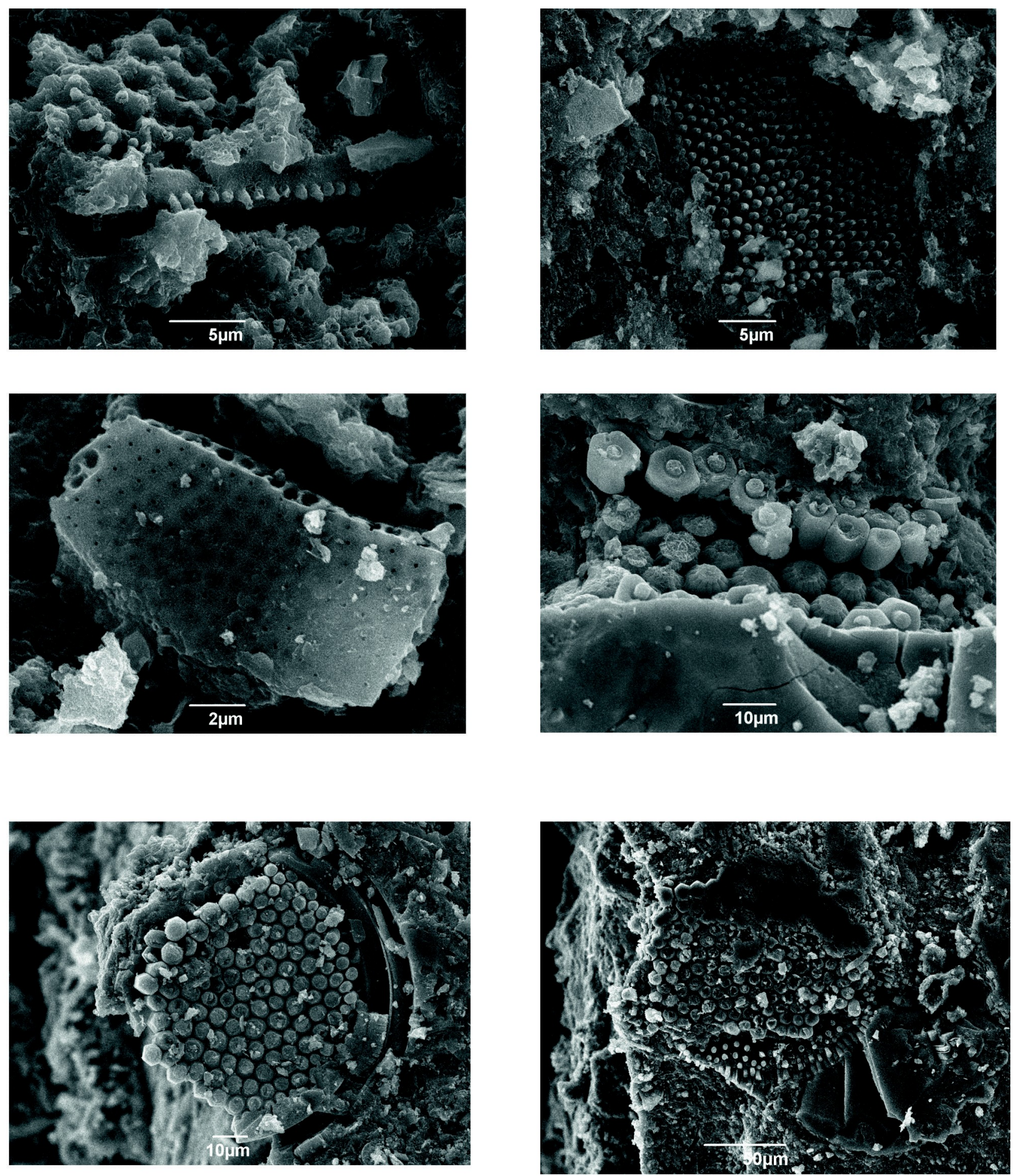


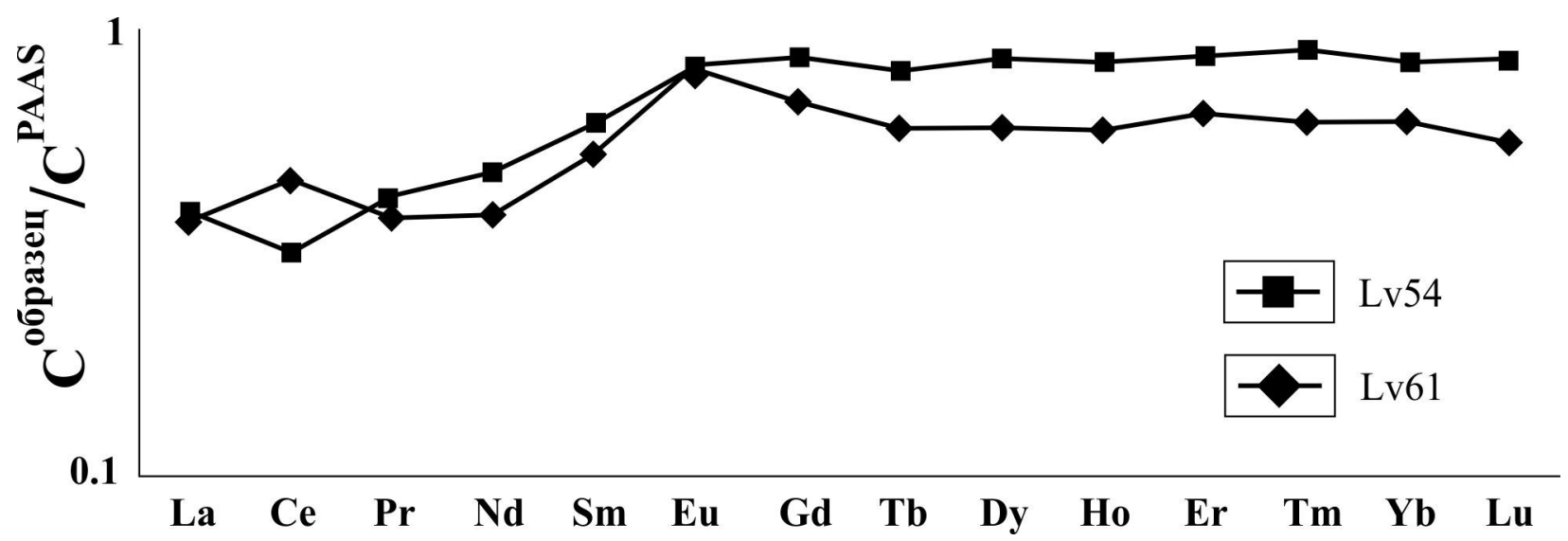




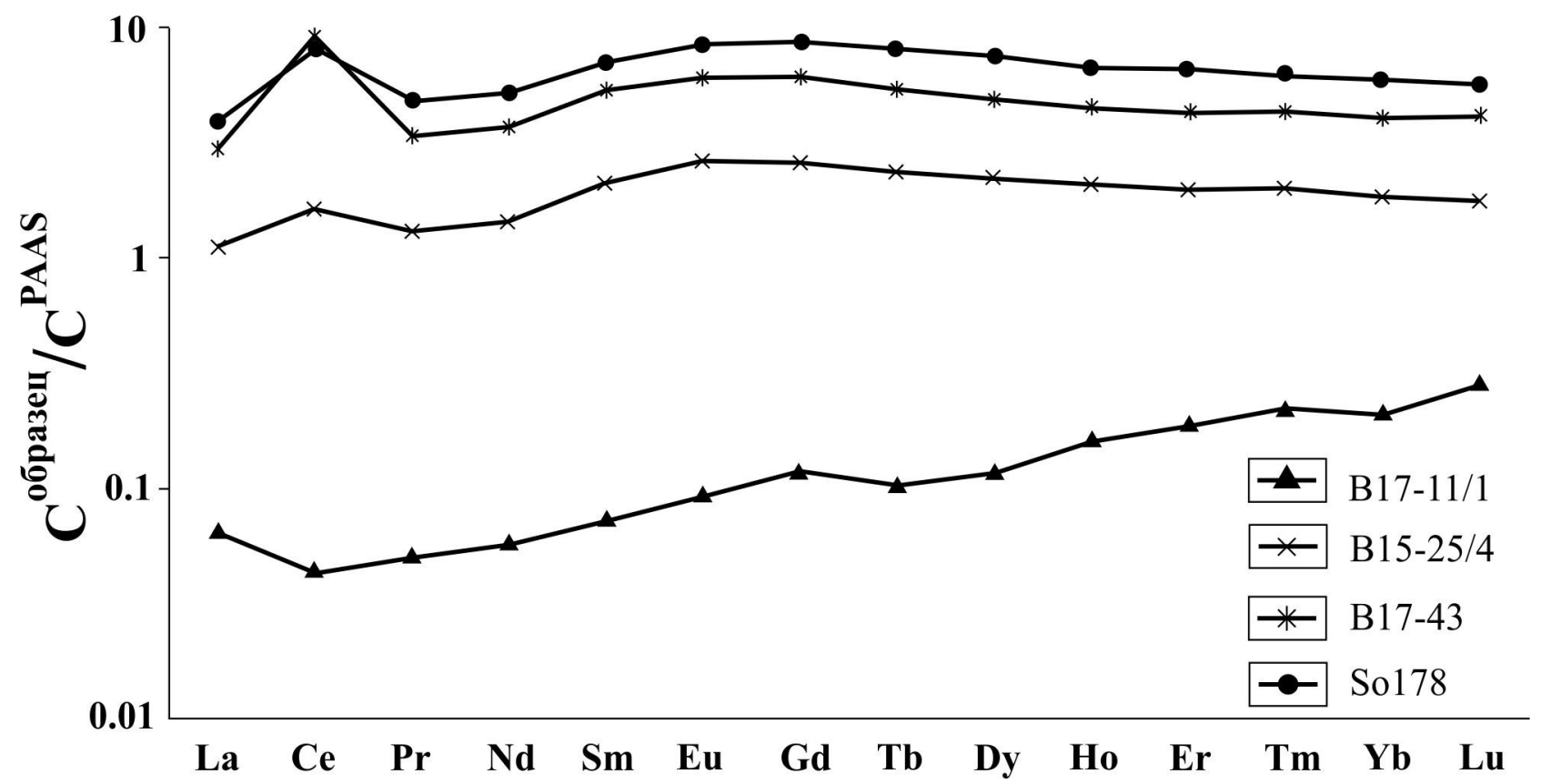



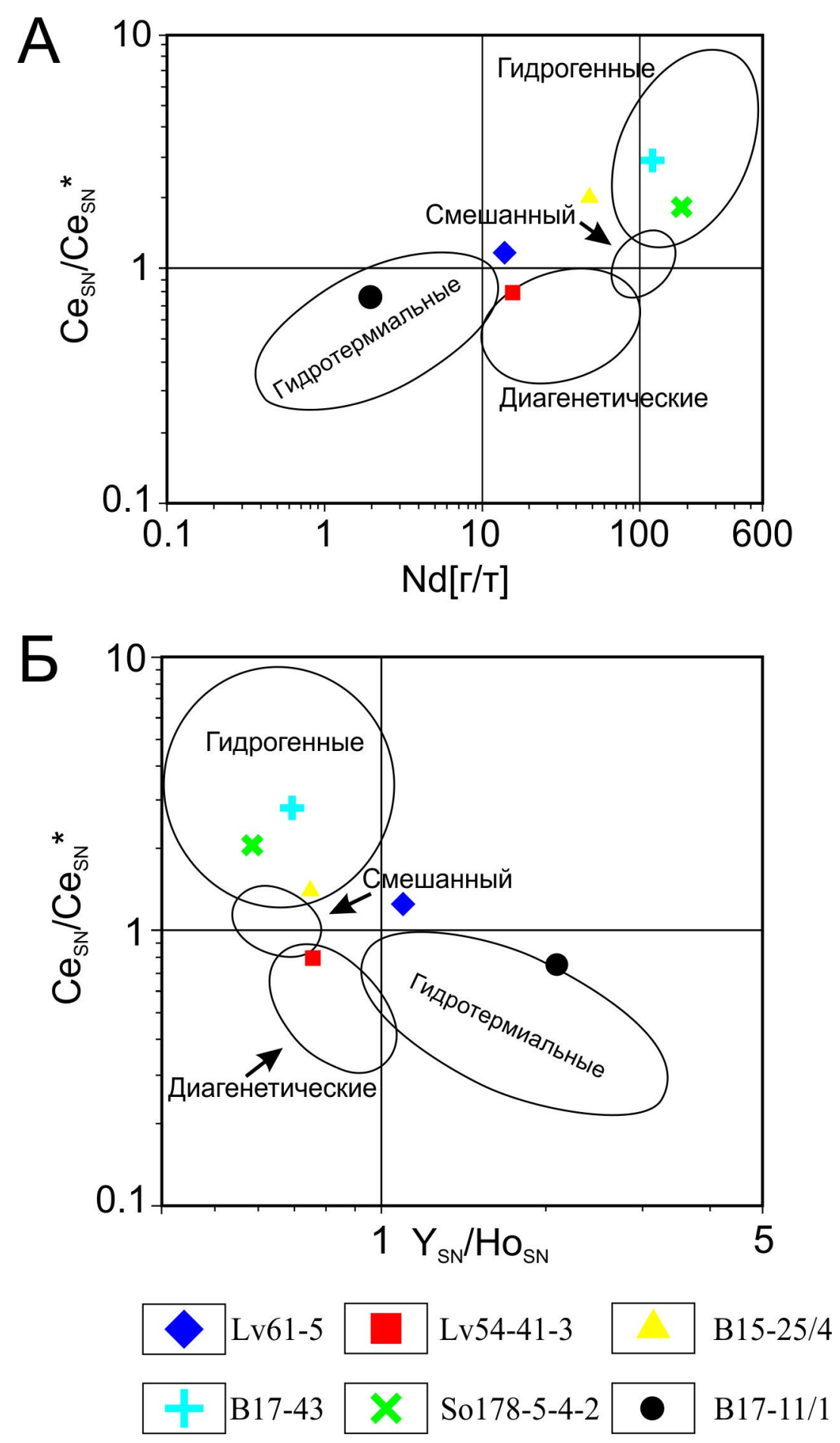